\title{
DEMONSTRATION OF THE DWPF FLOWSHEET IN THE SRNL SHIELDED CELLS USING ARP PRODUCT SIMULANT AND SB4 TANK 40 SLUDGE SLURRY
}

D. P. Lambert

J. M. Pareizs

B. R. Pickenheim

C. J. Bannochie

M. E. Stone

D. R. Click

E. K. Hansen

K. P. Crapse

D. T. Hobbs

May 2008 
WSRC-STI-2008-00130

Revision 0

\section{DISCLAIMER}

This report was prepared by Washington Savannah River Company (WSRC) for the United States Department of Energy under Contract No. DE-AC0996SR18500 and is an account of work performed under that contract. Neither the United States Department of Energy, nor WSRC, nor any of their employees makes any warranty, expressed or implied, or assumes any legal liability or responsibility for the accuracy, completeness, or usefulness, of any information, apparatus, or product or process disclosed herein or represents that its use will not infringe privately owned rights. Reference herein to any specific commercial product, process, or service by trademark, name, manufacturer, or otherwise does not necessarily constitute or imply endorsement, recommendation, or favoring of same by WSRC or by the United States Government or any agency thereof. The views and opinions of the authors expressed herein do not necessarily state or reflect those of the United States Government or any agency thereof.

\section{Printed in the United States of America}

Prepared For

U.S. Department of Energy 
WSRC-STI-2008-00130

Revision 0

Key Words: DWPF, Sludge, SB4, Salt Processing

Retention: Permanent

\section{DEMONSTRATION OF THE DWPF FLOWSHEET IN THE SRNL SHIELDED CELLS USING ARP PRODUCT SIMULANT AND SB4 TANK 40 SLUDGE SLURRY}

D. P. Lambert

J. M. Pareizs

B. R. Pickenheim

C. J. Bannochie

M. E. Stone

D. R. Click

E. K. Hansen

K. P. Crapse

D. T. Hobbs

May 2008 
WSRC-STI-2008-00130

Revision 0

\section{REVIEWS AND APPROVALS}

\section{AUTHORS:}

D. P. Lambert, Process Technology Programs

Date

J. M. Pareizs, Process Technology Programs

Date

B. R. Pickenheim, Process Technology Programs

Date

C. J. Bannochie, Process Technology Programs

Date

M. E. Stone, Process Technology Programs

Date

D. R. Click, Analytical Development

Date

E. K. Hansen, Process Technology Programs

Date

K. P. Crapse, Separations Science Programs

Date

D. T. Hobbs, Separations Science Programs

Date

\section{TECHNICAL REVIEWER:}

D. C. Koopman, Process Technology Programs

Date 
WSRC-STI-2008-00130

Revision 0

\section{APPROVERS:}

C. C. Herman, Manager, Process Technology Programs

Date

S. D. Fink, Manager, Separations Science Programs

Date

J. C. Griffin, Research Programs Manager, E\&CPT

Date

J. E. Occhipinti, Manager,

Date

Process Cognizant Engineering - Waste Solidification Engineering 


\section{EXECUTIVE SUMMARY}

The radioactive startup of two new SRS processing facilities, the Actinide Removal Process (ARP) and the Modular Caustic-Side-Solvent-Extraction Unit (MCU) will add two new waste streams to the Defense Waste Processing Facility (DWPF). The ARP will remove actinides from the $5.6 \mathrm{M}$ salt solution resulting in a sludge-like product that is roughly half monosodium titanate (MST) insoluble solids and half sludge insoluble solids. The ARP product will be added to the Sludge Receipt and Adjustment Tank (SRAT) at boiling and dewatered prior to pulling a SRAT receipt sample. The cesium rich MCU stream will be added to the SRAT at boiling after both formic and nitric acid have been added and the SRAT contents concentrated to the appropriate endpoint.

A concern was raised by an external hydrogen review panel that the actinide loaded MST could act as a catalyst for hydrogen generation (Mar 15, 2007 report, Recommendation 9). ${ }^{1}$ Hydrogen generation, and it's potential to form a flammable mixture in the off-gas, under SRAT and Slurry Mix Evaporator (SME) processing conditions has been a concern since the discovery that noble metals catalyze the decomposition of formic acid., 3 Radiolysis of water also generates hydrogen, but the radiolysis rate is orders of magnitude lower than the potential noble metal catalyzed generation. ${ }^{4}$ As a result of the concern raised by the external hydrogen review panel, hydrogen generation was a prime consideration in this experiment. Testing was designed to determine whether the presence of the irradiated ARP simulant containing MST caused uncontrolled or unexpected hydrogen production during experiments simulating the DWPF Chemical Process Cell (CPC) due to activation of titanium.

A Shielded Cells experiment, SC-5, was completed using SB4 sludge a blend of Tank $40^{5}$ sludge combined with an ARP product produced from simulants by SRNL researchers. The blend was designed to be prototypic of planned DWPF SRAT and SME cycles. As glass quality was not an objective in this experiment, no vitrification of the SME product was completed. The results from this experiment were compared to the results from experiment SC-1, a similar experiment with SB4 sludge without added ARP product.

Summary results related to the primary test objective, hydrogen generation, were as follows:

- The SRAT cycle hydrogen generation rate, scaled to a 6000 gallon batch, peaked at 0.0633 $\mathrm{lb} / \mathrm{hr} \mathrm{H}_{2}$, well below the DWPF limit of $0.65 \mathrm{lb} \mathrm{H}_{2} / \mathrm{hr}$ but higher than seen in the SC-1 run. The SME cycle hydrogen generation, scaled to a 6000 gallon batch, peaked at $0.104 \mathrm{lb} \mathrm{H}_{2} / \mathrm{hr}$, below the DWPF limit of $0.223 \mathrm{lb} \mathrm{H}_{2} / \mathrm{hr}$ but significantly higher than seen during the SC-1 run.

- This experiment should be considered conservative for hydrogen generation compared to planned ARP and SWPF processing because of the elevated levels of noble metals added to the ARP simulant. SB4 sludge is higher in noble metals relative to previous sludge batches, and the ARP simulant was higher for all noble metals compared to the sludge. It is expected that this experiment will bound future salt processing under nominal processing conditions.

- The addition of the ARP simulant to SC-5 is believed to be responsible for the increase in hydrogen. While the generation rate was higher than seen in the test without ARP, the timing and nature of the hydrogen generation curve was consistent with previous hydrogen generation behavior seen for increased levels of noble metals or formic acid. Therefore, it 
does not appear that a new mechanism for hydrogen generation was created through the activation of the MST.

All SRAT cycle processing limits were met. At the completion of the SRAT cycle, the nitrite concentration was less than $1000 \mathrm{mg} / \mathrm{kg}$ and the mercury concentration was less than $0.45 \mathrm{wt} \%$ mercury, meeting DWPF processing limits.

Other significant observations from the ARP processing include:

- The caustic sludge concentration and ARP addition phases were both completed with only foaming noted as a significant processing issue. SC-5 used DWPF's antifoam strategy of 200 ppm antifoam prior to processing and an additional 200 ppm each four hours of boiling. There were no foam-overs, although foam was persistent throughout processing. Additions of antifoam demonstrated that Antifoam 747 was effective in controlling foaming.

- Foaming was evident throughout processing, but was more persistent in the SME cycle. During the SRAT cycle, two additional $100 \mathrm{ppm}$ antifoam additions were made to control foam during formic acid addition and midway through reflux. Seven $100 \mathrm{ppm}$ antifoam additions were made during SME processing, which was four more than planned (100 ppm prior to initial heatup and 100 ppm added each 8 hours during boiling).

The testing demonstrated that hydrogen generation rate was below DWPF's operating limits with irradiated ARP simulant. Based on what is known about hydrogen generation from typical SRNL testing, hydrogen generation behavior in the SC-5 test appears to be consistent with previous simulant and radioactive slurry behavior. As resources permit, further testing could be performed to more clearly understand any changes in behavior that are associated solely with the inclusion of MST or the ARP process itself. To accomplish this goal, the following path forward could be implemented:

1. Repeat experiment SC-5 with ARP product containing irradiated MST but having no added noble metals. If MST is the catalytic source, then a test with noble metal free ARP simulant should produce similar hydrogen to the SC-5 run.

2. Perform testing with simulants to determine the efficiency of MST sorbed noble metals compared to noble metals added to the ARP product. This test would provide data to indicate whether MST is more efficient at sorbing soluble noble metals from the salt solution, forming a more active noble metal.

3. Transfer a sample of the actual ARP product from DWPF to SRNL to perform testing against a run without ARP. This will mitigate any potential differences caused by simulant fabrication.

To ensure that bounding levels of ARP noble metals have been considered, future feeds for both ARP and SWPF should be analyzed for Pd, Rh, and Ru since high concentrations of these noble metals in ARP and SWPF will likely lead to higher hydrogen generation in DWPF CPC processing. Presently, only Pd is reported by SRNL for salt solutions, although all 3 noble metal could be estimated based on the ICP-MS results. 


\section{TABLE OF CONTENTS}

\begin{tabular}{|c|c|}
\hline \multicolumn{2}{|c|}{ 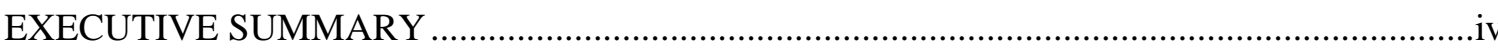 } \\
\hline \multirow{2}{*}{\multicolumn{2}{|c|}{$\begin{array}{l}\text { ABLE OF CONTENTS } \\
\text { IST OF FIGURES }\end{array}$}} \\
\hline & \\
\hline \multicolumn{2}{|c|}{ 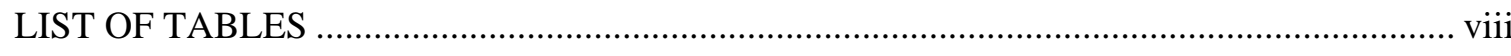 } \\
\hline \multicolumn{2}{|c|}{ LIST OF ACRONYMS ... } \\
\hline \multicolumn{2}{|c|}{1.0 INTRODUCTION AND BACKGROUND } \\
\hline \multicolumn{2}{|c|}{2.0 APPROACH } \\
\hline \multicolumn{2}{|c|}{ 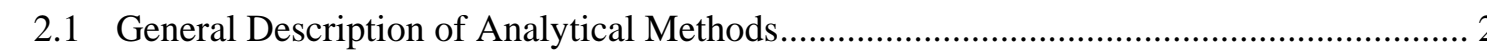 } \\
\hline 2.2 Pro & Production of Actinide Removal Product Simulant .................................................. 2 \\
\hline $2.3 \mathrm{Cal}$ & Caustic Concentration of the SRAT Receipt Sample \\
\hline 2.4 Che & Chemical Process Cell (CPC) Processing (SRAT Cycle, SME Cycle)................................ \\
\hline $2.5 \mathrm{Rh}$ & Rheology \\
\hline \multicolumn{2}{|c|}{ 3.0 RESULTS AND DISCUSSION } \\
\hline & 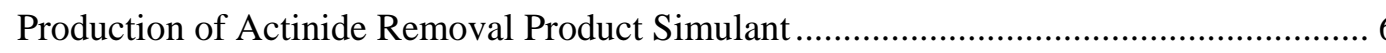 \\
\hline \multirow{2}{*}{\multicolumn{2}{|c|}{ 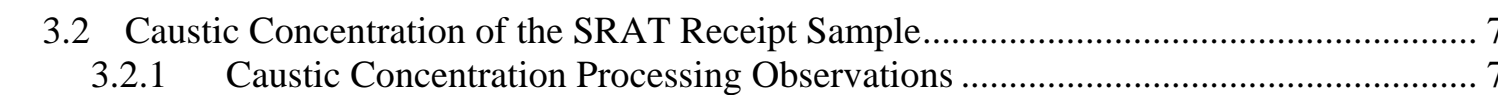 }} \\
\hline & \\
\hline 3.2.2 & Caustic Concentration Sample Results (Excluding Noble Metals) …..................... \\
\hline 3.2 .3 & Caustic Concentration Sample Results (Noble Metals)...................................... 10 \\
\hline \multicolumn{2}{|l|}{3.2 .4} \\
\hline \multicolumn{2}{|r|}{ 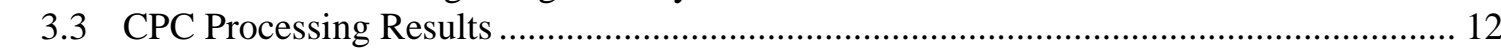 } \\
\hline 3.3 .1 & Processing Results \\
\hline 3.3.2 & SRAT and SME Cycle Processing Observations \\
\hline 3.3.3 & SRAT and SME Cycle Sample Results \\
\hline 3.3.4 & SRAT and SME Cycle Anion Destruction and Conversion .................................... 15 \\
\hline 3.3 .5 & SRAT and SME Cycle Off-gas Analysis (Excluding Hydrogen).. \\
\hline 3.3.6 & SRAT and SME Cycle Off-gas Analysis (Hydrogen Only). \\
\hline 3.3.7 & Metal So \\
\hline & \\
\hline $0 \mathrm{CON}$ & ION \\
\hline .0 REC & IENDATIONS . \\
\hline $0 \mathrm{REF}$ & NCES... \\
\hline 0 ACK & VLEDGEMENTS \\
\hline PPENI & 2А T PRODUCT AND SA \\
\hline
\end{tabular}




\section{LIST OF FIGURES}

Figure 2-1. Schematic of SRAT Equipment Set-Up ....................................................................

Figure 3-1. Photograph of Persistent Foam during Caustic Concentration ......................................8

Figure 3-2 Off-gas Concentration during Caustic Concentration and ARP Addition.....................12

Figure 3-3. Carbon Dioxide Generation during SC-1 and SC-5 SRAT Cycles ...........................17

Figure 3-4. Nitrous Oxide Generation during SC-1 and SC-5 SRAT Cycles .............................17

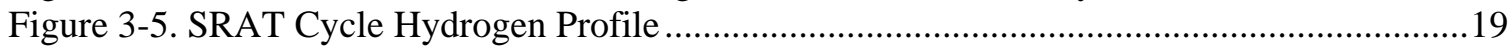

Figure 3-6. SME Cycle Hydrogen Profile ...................................................................................19

Figure 3-7. Hydrogen Generation Profile Comparison between SC-5 SRAT cycle and

Simulant Run RhRuHg1, a SRAT cycle with added Rh, Rh, and Hg, DWPF Scale lb/hr

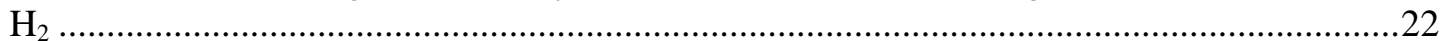

Figure 3-8a and Figure 3-8b. Flow Curves for SC-5 Sludge Concentrate Sample (w/o/ ARP) .....24

Figure 3-9a and Figure 3-9b. Flow Curves for SC-5 SRAT Receipt Sample (w/ ARP) ................25

Figure 3-10a and Figure 3-10b. Flow Curves for SC-5 SME Product Sample .............................26 


\section{LIST OF TABLES}

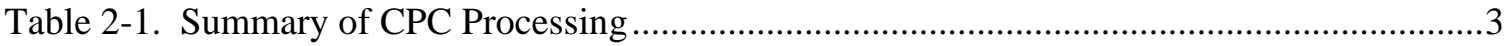

Table 2-2. MV I and MV II Rotor Specifications and Flow Curve Program ..................................5

Table 3-1. Analytical Results of ARP Simulant prepared for SC-5 ..........................................6

Table 3-3. ICP-AES Characterization Results of the SB4 Tank 40 with ARP Product (SC-5

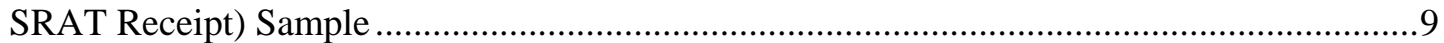

Table 3-4. Characterization Results and Acid Calculation Inputs of the SB4 Tank 40 with ARP Product (SC-5 SRAT Receipt) Sample with Comparison to SB4 Blend SRAT Receipt (SC-1) Sample and Tank 40 WAPS Sample ${ }^{5}$

Table 3-5. Concentrations of Noble Metals, Titanium and Silver in wt \% of Total Dried

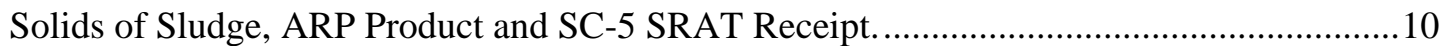

Table 3-6. Inputs for SC-1 and SC-5 Acid Calculations ..........................................................13

Table 3-7. Acid Calculation Inputs of the of the SB4 Tank 40 with ARP Product (SC-5 SRAT Receipt) Sample with Comparison to SB4 Blend SRAT Receipt (SC-1) Sample.......13

Table 3-8. Required Acid Needed as Predicted by DWPF's Acid Calculation.............................14

Table 3-9. SRAT Product Characterization Results......................................................................15

Table 3-10. SME Product Weight Percent Solids and Densities................................................15

Table 3-11. Comparison of Assumed and Measured Anion Destruction and Conversion in the SRAT Cycles.

Table 3-12. Comparison of Assumed and Measured Anion Destruction and Conversion in the SME Cycles.

Table 3-13. Maximum Observed Volume Percent and Generation Rates (DWPF Scale) of Hydrogen, Carbon Dioxide, and Nitrous Oxide during the SC-5 SRAT and SME Testing...18

Table 3-14. Maximum Observed Volume Percent and Generation Rates (DWPF Scale) of Hydrogen, Carbon Dioxide, and Nitrous Oxide during the SC-1 SRAT and SME Testing. ..18

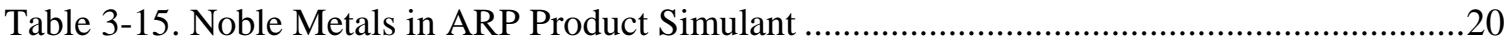

Table 3-16. Yield Stress and Plastic Viscosity Results for SC-5 Samples...................................23

Table 3-17. Conditions of Rheology Measurements ......................................................................23

Table A-1: SRAT Receipt, SRAT Product and SME Product ICP-ES Sample Results ................32

Table A-2: SRAT Receipt, SRAT Product and SME Product ICP-MS Sample Results, mg/kg ...33 


\section{LIST OF ACRONYMS}

ACTL

AC\&T

$\mathrm{AD}$

AF

AR

ARG

ARM

ARP

ASSM

CPC

CS

DWPF

FAVC

GC

HLW

IC

ICP-AES

ICP-MS

IS

LIMS

LWO

MAR

MCU

MST

MWWT

NIST

PCCS

PMP

PSAL

PS\&E

QA

REDOX

SB3

SB4

SME

SMECT

SRAT

SRNL

SRS

SS

TIC

TOC

TS

TT\&QAP

TTR

WAPS

WL
Aiken County Technologies Laboratory

Actinide Chemistry \& Technology

Analytical Development

Alkali Fusion (Digestion)

Aqua Regia (Digestion)

Analytical Reference Glass

Approved Reference Material

Actinide Removal Process

Analytical Sample Support Matrix

Chemical Process Cell

Calcine Solids

Defense Waste Processing Facility

Formic Acid Vent Condenser

Gas Chromatograph

High Level Waste

Ion Chromatography

Inductively Coupled Plasma - Atomic Emission Spectroscopy

Inductively Coupled Plasma - Mass Spectroscopy

Insoluble Solids

Laboratory Information Management System

Liquid Waste Organization

Measurement Acceptability Region

Modular Caustic Side Solvent Extraction Unit

Monosodium Titanate

Mercury Water Wash Tank

National Institute of Standards and Testing

Product Composition Control System

Polymethyl propylene

Process Science Analytical Laboratory

Process Science and Engineering Section

Quality Assurance

REDuction / OXidation potential

Sludge Batch 3

Sludge Batch 4

Slurry Mix Evaporator

Slurry Mix Evaporator Condensate Tank

Sludge Receipt and Adjustment Tank

Savannah River National Laboratory

Savannah River Site

Soluble Solids

Total Inorganic Carbon

Total Organic Carbon

Total Solids

Task Technical and Quality Assurance Plan

Technical Task Request

Waste Acceptance Product Specification

Waste Loading 


\subsection{INTRODUCTION AND BACKGROUND}

The radioactive startup of two new SRS processing facilities, the Actinide Removal Process (ARP) and the Modular Caustic-Side-Solvent-Extraction Unit (MCU) will add two new waste streams to the Defense Waste Processing Facility (DWPF). The ARP will remove actinides from the $5.6 \mathrm{M}$ salt solution resulting in a sludge-like product that is roughly half monosodium titanate (MST) insoluble solids and half sludge insoluble solids. The ARP product will be added to the Sludge Receipt and Adjustment Tank (SRAT) at boiling and dewatered prior to pulling a SRAT receipt sample. The cesium rich MCU stream will be added to the SRAT at boiling after both formic and nitric acid have been added and the SRAT contents concentrated to the appropriate endpoint.

A concern was raised by an external hydrogen review panel that the actinide loaded MST could act as a catalyst for hydrogen generation (Mar 15, 2007 report, Recommendation 9). ${ }^{1}$ Hydrogen generation, and it's potential to form a flammable mixture in the off-gas, under SRAT and Slurry Mix Evaporator (SME) processing conditions has been a concern since the discovery that noble metals catalyze the decomposition of formic acid. ${ }^{2,3}$ Radiolysis of water also generates hydrogen, but the radiolysis rate is orders of magnitude lower than the noble metal catalyzed generation. ${ }^{4}$ As a result of the concern raised by the external hydrogen review panel, hydrogen generation was a prime consideration in this experiment. Testing was designed to determine whether the presence of the irradiated ARP simulant containing MST caused uncontrolled or unexpected hydrogen production during experiments simulating the DWPF Chemical Process Cell (CPC) due to activation of titanium.

A Shielded Cells experiment, SC-5, was completed using SB4 sludge from Tank $40^{5}$ combined with an ARP product produced from simulants by SRNL researchers. The blend of sludge and MST was designed to be prototypic of planned DWPF SRAT and SME cycles. As glass quality was not an objective in this experiment, no vitrification of the SME product was completed. The results from this experiment were compared to the results from experiment SC-1, a similar experiment with SB4 sludge without added ARP product.

This report documents:

- The preparation and subsequent composition of the ARP product.

- The preparation and subsequent compositional characterization of the SRAT Receipt sample. Additional details will be presented concerning the noble metal concentration of the ARP product and the SRAT receipt sample. Also, calculations related to the amount of formic and nitric acid added during SRAT processing will be presented as excess formic acid will lead to additional hydrogen generation.

- Highlights from processing during the SRAT cycle and SME cycle (CPC processing). Hydrogen generation will be discussed since this was the prime objective for this experiment.

- A comparison of CPC processing between SC-1 (without ARP simulant) and SC-5.

This work was controlled by a Task Technical and Quality Assurance Plan (TTQAP) ${ }^{6}$, and analyses were guided by an Analytical Sample Support Matrix (ASSM) ${ }^{7}$. This Research and Development (R\&D) was completed to support operation of DWPF. 


\subsection{APPROACH}

\subsection{General Description of Analytical Methods}

Analyses for this task used guidance of an $\operatorname{ASSM}^{7}$. Sample request forms were used for samples to be analyzed, and analyses followed the guidelines and means of sample control stated in the ASSM for the task. A unique laboratory identification management system (LIMS) number was assigned to each sample for tracking purposes. Analyses were performed using approved analytical and Quality Assurance (QA) procedures.

Procedures for analysis of the simulant material can be found in reference 8 . For the radioactive materials, procedures and work instructions for density, percent solids, and supernate and slurry dilutions are also given in reference 8. Procedures for digestions and sample analyses are given in reference 9 .

\subsection{Production of Actinide Removal Product Simulant}

A simulant of the product of the ARP process was prepared by Actinide Chemistry \& Technology (AC\&T) to mimic the actual production as much as possible. A number of modifications were made, however, in order to favor conditions for conservatively high noble metal loading on MST and to simplify preparation. These modifications were made based on the assumption that higher noble metal loading on MST would be expected to favor higher hydrogen generation, since noble metals are known to catalyze the decomposition of formic acid to generate hydrogen.

In typical production of actual ARP product for transfer to DWPF, 5.6 M sodium waste feed containing 0.6 g sludge solids per liter is treated with $15 \mathrm{wt} \%$ MST to generate a resulting slurry containing $0.4 \mathrm{~g}$ MST per liter of diluted feed. The slurry is then crossflow filtered to reduce the volume. Oxalic acid is used in the cleaning solution for rinsing the cross-flow filters followed by neutralization of the resulting stream. These steps are typically carried out in multiple strikes, and the resultant MST/sludge solids heel is washed with inhibited water to adjust the sodium concentration to approximately $0.5 \mathrm{M}$ sodium. The resulting ARP product is approximately $5 \mathrm{wt} \%$ insoluble solids (with the insoluble solids composed of approximately $40 \%$ MST solids and $60 \%$ sludge solids).

For the purpose of this study, the ARP product simulant was prepared with a number of modifications from the actual process. 5.6 M sodium nonradioactive simulated waste solution supersaturated with noble metals ( $\mathrm{Ru}, \mathrm{Rh}, \mathrm{Pd})$, but not containing sludge solids, was contacted with $15 \mathrm{wt} \%$ MST to generate a 0.4 g MST per liter slurry. Sludge solids were omitted from this step in order to favor the saturation of noble metals on the MST without sludge present to compete sorption of the noble metals. After the volume of the MST with noble metals slurry was reduced, nonradioactive simulated sludge solids (SB4 simulant) were then added such that insoluble solids of the resulting slurry were approximately $40 \%$ MST and $60 \%$ sludge solids. The resulting $5.6 \mathrm{M}$ sodium slurry with MST and sludge solids was then irradiated to simulate the irradiation expected during ARP processing and storage in DWPF. A conservative hold time (3 months) was assumed based on the longer ARP facility processing time. The bounding curie content (5.25 Ci/gal based on Cs-137) used for determining the irradiation dose was based on Salt Waste Processing Facility Planning. ${ }^{10}$ No MCU stream was added during the DWPF processing demonstration.

\subsection{Caustic Concentration of the SRAT Receipt Sample}

The blend of ARP and sludge was equivalent to 5,530 gallons of sludge to 1,470 gallons of ARP to produce 6,000 gallons of slurry after evaporation, as predicted for ARP Case K/L ${ }^{11}$ (Dual reactors, 4 or 8 hour MST strike, $0.1 \mu \mathrm{m}$ filter) to maximize loading of MST in DWPF SRAT processing. After 
concentration, a pre-SRAT cycle sample will be analyzed to perform acid calculations. No MCU stream was added during the DWPF processing demonstration.

SC-5 was the first Shielded Cells experiment to simulate both the caustic evaporation of sludge and the caustic evaporation of the blend of ARP slurry with sludge. Since DWPF has been experiencing foaming and air entrainment issues during their caustic evaporation, SRNL was asked to pay careful attention to the foaming behavior of the slurry. An antifoam addition strategy was developed to deal with the foaming noted in the DWPF caustic evaporation, namely 200 ppm antifoam 747 before heat-up and 200 ppm every four hours. SRNL testing was designed to validate this strategy or develop a new antifoam strategy for caustic boiling.

\subsection{Chemical Process Cell (CPC) Processing (SRAT Cycle, SME Cycle)}

The SRAT and SME cycles were conducted following procedures in the Process Science and Engineering Section procedure manual. ${ }^{12}$ A summary of each cycle is presented in Table 2-1 below.

Table 2-1. Summary of CPC Processing

\begin{tabular}{|c|c|}
\hline SRAT Processing & SME Processing \\
\hline $\begin{array}{ll}\text { - } & \text { Caustic boiling } \\
\text { - } & \text { ARP Addition } \\
\text { - } & \text { Receipt Sample } \\
\text { - } & \text { Acid Calculation } \\
\text { - } & \text { Heating of SRAT Receipt to } 93{ }^{\circ} \mathrm{C} \\
\text { - } & \text { Addition of nitric and formic acids } \\
\text { - } & \text { Heat to boiling } \\
\text { - } & \text { Concentration (water removal) to a } \\
& \text { target wt\% total solids } \\
\text { - } & \text { Reflux for } 12 \text { hours }\end{array}$ & 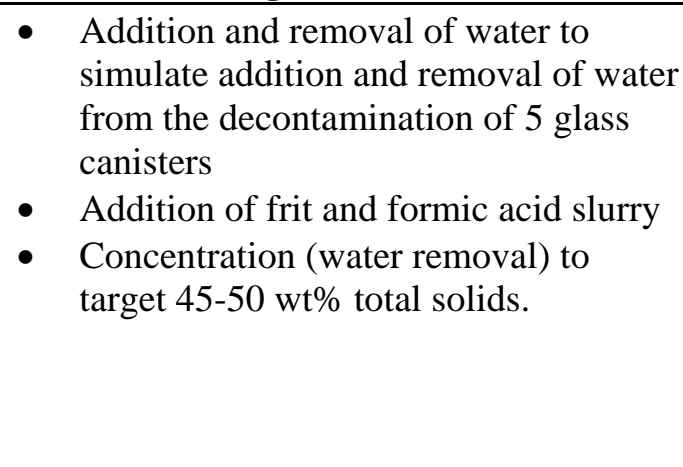 \\
\hline
\end{tabular}

Processing was performed using a vessel nominally designed for one liter of sludge. The SRAT rig was assembled and tested in the SRNL Shielded Cells Mockup area and placed into the Shielded Cells fully assembled. A detailed description of the SRAT rig and testing of the rigs can be found in references 13 and 14. The intent of the equipment is to functionally replicate the DWPF processing vessels. The glass kettle is used to replicate both the SRAT and the SME, and it is connected to the SRAT Condenser and the Mercury Water Wash Tank (MWWT). Because the DWPF Formic Acid Vent Condenser (FAVC) does not directly impact SRAT and SME chemistry, it is not included in SRNL Shielded Cells CPC processing. Instead, a simple "cold finger" condenser is used to cool off-gas to approximately $20{ }^{\circ} \mathrm{C}$ below ambient to remove excess water before the gas reaches the gas chromatograph for characterization. The Slurry Mix Evaporator Condensate Tank (SMECT) is represented by a sample bottle that is used to remove condensate through the MWWT. For the purposes of this paper, the condensers and wash tank are referred to as the off-gas components. A sketch of the experimental setup is given as Figure 2-1.

SRAT processing included the addition of nitric and formic acid at DWPF prototypic rates, the dewater time, plus an additional 12 hours of reflux to simulate DWPF processing conditions. Concentrated nitric acid (50-wt\%) and formic acid (90-wt\%) were used to acidify the sludge and perform neutralization and reduction reactions during processing. The amounts of acid to add for each run were determined using the SRNL acid calculation spreadsheet ${ }^{15}$. The split of the acid was determined using latest reductionoxidation, or REDOX, equation ${ }^{15}$, which utilizes the same acid addition equation used by DWPF. To 
account for the reactions that occur during processing, assumptions about nitrite destruction, nitrite-tonitrate conversion, and formate destruction were made for each run. The values used for each run are provided in Section 3.0.

SME processing included the time to evaporate water added to simulate the addition of water generated due to canister decontamination and the simulation of two equal additions of frit slurry followed by the time to evaporate the water added with this slurry and the time to dewater to the SME solids target. The SRAT/SME condenser was maintained at $25^{\circ} \mathrm{C}$ during the run, while the cold finger condenser, designed to simulate FAVC operations, remained below $5^{\circ} \mathrm{C}$.

SRAT and SME processing parameters are given in reference 16. Off-gas hydrogen, oxygen, nitrogen, nitrous oxide, and carbon dioxide concentrations were measured during the experiments using in-line instrumentation. Helium was introduced at a concentration of $0.5 \%$ of the total air purge as an inert tracer gas so that total amounts of generated gas and peak generation rates could be calculated. During the runs, the kettle was monitored to observe reactions that were occurring to include foaming, air entrainment, rheology changes, loss of heat transfer capabilities, and off-gas carryover. Observations were recorded in a laboratory notebook ${ }^{16}$ and are discussed in Section 3.0.

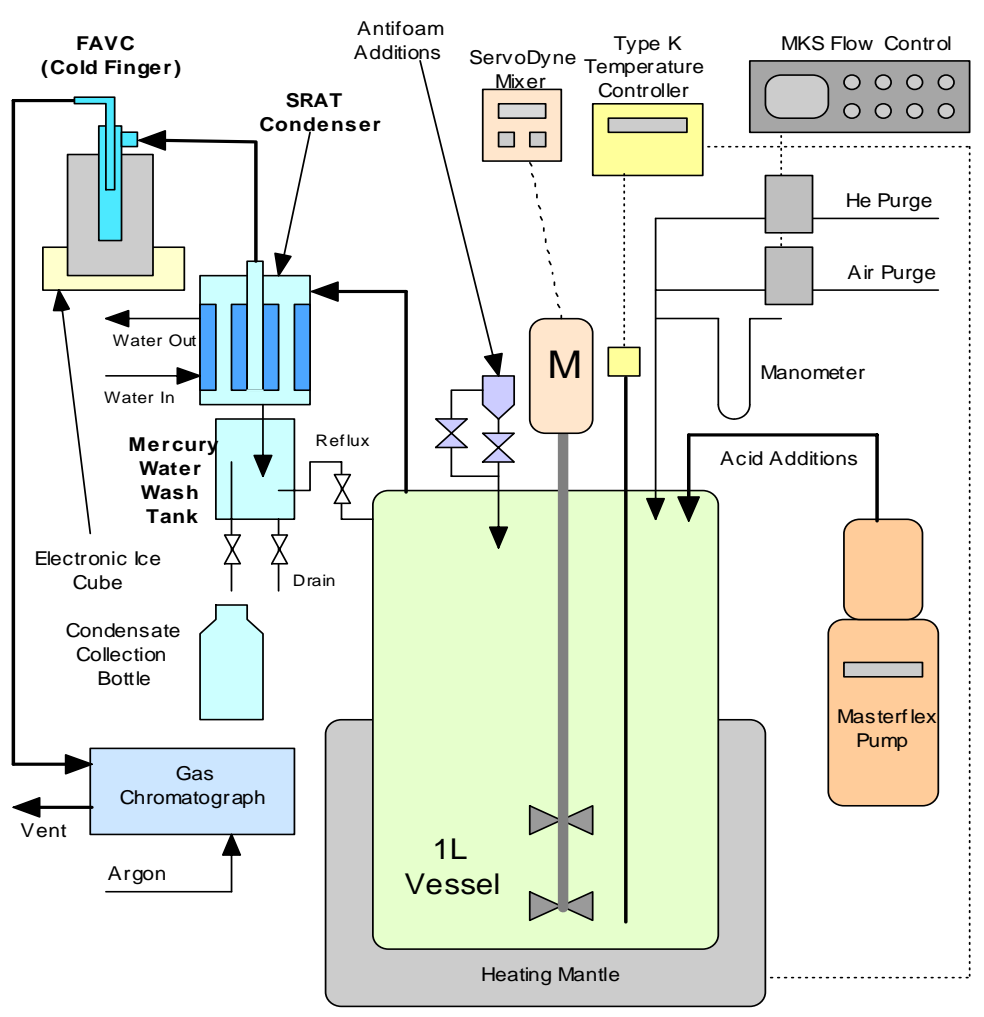

Figure 2-1. Schematic of SRAT Equipment Set-Up

\subsection{Rheology}

Rheological properties were determined using a Haake M5/RV30 rotoviscometer. The M5/RV30 is a Searle sensor system, where the bob rotates and the cup is fixed. The torque and rotational speed of the bob are measured. Heating/cooling of the cup/sample/bob is through a jacket that surrounds and holds the sample cup. The shear stress is determined from the torque measurement and is independent of 
rheological properties. Conditions that impact the measured torque are slip (material does not properly adhere to the rotor or cup), phase separation (buildup of liquid layer on rotor), sedimentation (particles settling out of the shearing zone), homogeneity of sample (void of air), lack of sample (annular gap not completely filled), excess sample (primarily impacts rheologically thin fluids), completely filling up the void below the bob (shear-free air buffer that is now filled with fluid), and Taylor vortices. The first five items yield lower stresses and the last three add additional stresses. The shear rate is geometrically determined using the equations of change (continuity \& motion) and is that for a Newtonian fluid. This assumption also implies that the flow field is fully developed and the flow is laminar.

The shear rate can be calculated for a non-Newtonian fluid using the measured data and fitting this data to the rheological model or corrected as recommended by Darby ${ }^{17}$. In either case, for shear thinning nonNewtonian fluids, typical of Savannah River Site (SRS) sludge wastes, the corrected shear rates are greater than their corresponding Newtonian shear rates, resulting in a thinner fluid. Correcting the flow curves will not be performed in this task, resulting in reporting slightly more viscous rheological properties.

The bob typically used for measuring tank sludge or SRAT product is the MV I rotor. For SME product, the MV II rotor is used to perform the measurements, due to the larger frit particles that are present in the SME product. The MV II has a larger gap to accommodate the larger frit particles. The shape, dimensions, and geometric constants for the MV I and MV II rotors are provided in Table 2-2. Prior to performing the measurements, the rotors and cups are inspected for physical damage. The torque/speed sensors and temperature bath are verified for functional operability using a bob/cup combination with a National Institute of Standards and Technology (NIST) traceable Newtonian oil standard, using the MV I rotor. The resulting flow curves are then fitted as a Newtonian fluid and this calculated viscosity must be within $\pm 10 \%$ of the reported NIST viscosity at a given temperature for the system to be considered functionally operable. A N10 oil standard was used to verify system operability prior to the sludge measurements.

The flow curves for the sludge were fitted to the down curves using the Bingham Plastic rheological model, Equation 2-1, where $\tau$ is the measured stress $(\mathrm{Pa}), \tau_{\mathrm{o}}$ is the Bingham Plastic yield stress $(\mathrm{Pa}), \mu_{\infty}$ is the plastic viscosity (Pa.sec), and $\dot{\gamma}$ is the measured shear rate $\left(\sec ^{-1}\right)$. During all of these measurements, the sample typically remained in the cup for the second measurement, due to the limited quantity of sample available. If thixotropic properties or unique flow behavior were obvious on the first sample measurement, then efforts were made to perform additional measurements by reloading the sample.

$$
\tau=\tau_{o}+\mu_{\infty} \dot{\gamma}
$$

Table 2-2. MV I and MV II Rotor Specifications and Flow Curve Program

\begin{tabular}{|c|c|c|c|}
\hline Rotor Design & \multicolumn{3}{|c|}{ Dimensions and Flow Curve Program } \\
\hline & Rotor Type & MV I & MV II \\
\hline & Rotor radius - $\mathrm{R}_{\mathrm{i}}(\mathrm{mm})$ & 20.04 & 18.40 \\
\hline & Cup Radius - $\mathrm{R}_{\mathrm{a}}$ (mm) & 21.0 & 21.0 \\
\hline & Height of rotor -L (mm) & 60 & 60 \\
\hline & $\begin{array}{l}\text { Sample Volume }\left(\mathrm{cm}^{3}\right) \\
\text { minimum }\end{array}$ & 40 & 55 \\
\hline & A factor (Pa/\%torque) & 3.22 & 3.76 \\
\hline & $\mathrm{M}$ factor $\left(\mathrm{s}^{-1} / \% \mathrm{RPM}\right)$ & 11.7 & 4.51 \\
\hline & Shear rate range $\left(\mathrm{s}^{-1}\right)$ & $0-600$ & $0-300$ \\
\hline & Ramp up time (min) & 5 & 5 \\
\hline & Hold time (min) & 1 & 1 \\
\hline & Ramp down time (min) & 5 & 5 \\
\hline
\end{tabular}




\subsection{RESULTS AND DISCUSSION}

\subsection{Production of Actinide Removal Product Simulant}

The ARP simulant was produced by contacting a mixture of MST with a simulated waste solution saturated with noble metals $\mathrm{Ru}, \mathrm{Rh}$ and $\mathrm{Pd}$. Simulated sludge solids were added to the mixture and filtered using nominal 0.1 micron Mott (1110-8.5-40-.028-0.1-A sheet 316L stainless) submersible filters. The mixture was irradiated for 10.2 hours at 4.198E5 R/h in the SRNL cobalt gamma source (equivalent to a 3-month dose at a bounding gamma activity of $5.25 \mathrm{Ci} /$ gal based on ${ }^{137} \mathrm{Cs}$ in the SWPF). The soluble salt fraction of the material was then diluted to reduce the soluble salt content to that expected for the ARP product that will be sent to the DWPF. This bounding ARP simulant represents material that contained a conservatively high concentration of noble metals and was irradiated to a much greater extent than that expected under normal operations.

Table 3-1. Analytical Results of ARP Simulant prepared for SC-5.

\begin{tabular}{|l|c|}
\hline ANALYSIS & $\begin{array}{c}\text { SC-5 ARP } \\
\text { SIMULANT }\end{array}$ \\
\hline Density, g/mL & 1.08 \\
\hline Total Solids, Wt \% on slurry basis & 8.75 \\
\hline Insoluble Solids, Wt \% on slurry basis & 4.92 \\
\hline Soluble Solids, Wt \% on slurry basis & 3.83 \\
\hline Calcined Solids, Wt \% on slurry basis & 5.46 \\
\hline Nitrite, mg/kg on slurry basis & $<1,602$ \\
\hline Nitrate, mg/kg on slurry basis & 14,125 \\
\hline Sulfate, mg/kg on slurry basis & 4,613 \\
\hline Total Inorganic Carbon, mg/kg on slurry basis & 644 \\
\hline Total Organic Carbon, mg/kg on slurry basis & 552 \\
\hline Base Equivalents (mol/L slurry) & 0.264 \\
\hline Al, mg/kg slurry basis & 5,180 \\
\hline Ba, mg/kg slurry basis & 22.4 \\
\hline $\mathrm{Ca}, \mathrm{mg} / \mathrm{kg}$ slurry basis & 678 \\
\hline $\mathrm{Cr}, \mathrm{mg} / \mathrm{kg}$ slurry basis & 24.5 \\
\hline $\mathrm{Cu}, \mathrm{mg} / \mathrm{kg}$ slurry basis & 11.1 \\
\hline Fe, mg/kg slurry basis & 7,460 \\
\hline $\mathrm{Mg}, \mathrm{mg} / \mathrm{kg}$ slurry basis & 585 \\
\hline $\mathrm{Mn}, \mathrm{mg} / \mathrm{kg}$ slurry basis & 1,610 \\
\hline $\mathrm{Na}, \mathrm{mg} / \mathrm{kg}$ slurry basis & 14,200 \\
\hline $\mathrm{Ni}, \mathrm{mg} / \mathrm{kg}$ slurry basis & 434 \\
\hline $\mathrm{Rh}, \mathrm{mg} / \mathrm{kg}$ slurry basis & 0.111 \\
\hline $\mathrm{Ru}, \mathrm{mg} / \mathrm{kg}$ slurry basis & 0.104 \\
\hline $\mathrm{S}, \mathrm{mg} / \mathrm{kg}$ slurry basis & 1,880 \\
\hline Ti, mg/kg slurry basis & 8,610 \\
\hline Zr, mg/kg slurry basis & 16.3 \\
\hline
\end{tabular}




\subsection{Caustic Concentration of the SRAT Receipt Sample}

The caustic concentration phase of the SC-5 experiment was designed to duplicate the processing expected in DWPF. After sludge is transferred into the DWPF SRAT, the sludge is concentrated to allow additional transfer of sludge (if needed) and to concentrate as needed prior to addition of the ARP slurry. The SRAT receipt sample was carefully prepared to produce slurry similar to the SRAT receipt sample for SC-1 (30 wt \% Tank 51/70 wt \% Tank 40 Blend - prior to SB4). The caustic concentration was completed in two phases on two separate days.

The SRNL testing of this blend is referred to as Shielded Cells-5 (SC-5). Testing of Sludge Batch 4/ARP simulant Blend SC-5 was completed at SRNL in January 2008. Specifics of the blend are provided below. Personnel prepared the SC-5 Blend in several steps. A portion of a Tank 40 sample (received November 2007) was concentrated from $14.4 \mathrm{wt} \%$ to $20.3 \mathrm{wt} \%$ total solids by evaporation (to match the SC-1 SRAT receipt solids). The concentrated sludge was sampled and the sample was retained for future rheology analysis. The irradiated ARP simulant was added to the concentrated sludge at boiling to produce the blend target. Finally, the combined mixture was evaporated to a target of $20.3 \mathrm{wt} \%$ total solids. The blend was sampled and analyzed in preparation for SRAT and SME Cycle tests.

- On 1-14-2008, $1521.81 \mathrm{~g}$ of sludge was pumped into the SRAT vessel (1521.44 g target) using a peristaltic pump. Also, $116.96 \mathrm{~g}$ of deionized (DI) water was added to rinse the sludge carboy and the pump tubing. The mass was designed to simulate the water addition resulting from starting pumps in DWPF. Because of pump water in-leakage in Tank 40 has diluted the SB4 sludge; $504.27 \mathrm{~g}$ of condensate were collected (target was $501.68 \mathrm{~g}$ ) to concentrate the sludge to $20.3 \mathrm{wt} \%$ total solids (match the SC-1 SRAT receipt concentration). A $93.56 \mathrm{~g}$ sample was pulled and retained for a future rheology study.

- On 1-15-2008, $254.05 \mathrm{~g}$ of ARP product were pumped into the SRAT vessel at $1.07 \mathrm{~mL} / \mathrm{min}$ (scaled to 8 gallons/minute in DWPF). Also, $116.96 \mathrm{~g}$ of DI water was added to rinse the pump tubing and simulate the water addition resulting from starting pumps in DWPF. $253.39 \mathrm{~g}$ of condensate was collected to concentrate the sludge to $20.3 \mathrm{wt} \%$ total solids (target was $261.51 \mathrm{~g}$ ). A 91.29 g sample was pulled and retained for a future rheology study. Also, a $66.39 \mathrm{~g}$ sample was pulled for SRAT receipt analyses. Based on a mass balance calculation, the SRAT receipt slurry mass after sampling was $949.9 \mathrm{~g}$ (target $954.8 \mathrm{~g}$ ). The resulting blend consisted of 92.2 wt \% insoluble solids from Tank 40 (SB4) and $7.8 \mathrm{wt} \%$ insoluble solids from the ARP simulant. After removal of two samples, an estimated $950 \mathrm{~g}$ of slurry were present in the SRAT vessel.

\subsubsection{Caustic Concentration Processing Observations}

As was discussed earlier, DWPF has been experiencing pressure surges that could be related to foaming during the caustic boiling phase of SRAT processing. The following antifoam addition strategy was used during experiment SC-5:

- 200 ppm addition prior to starting the caustic concentration

- 200 ppm addition every 4 hours thereafter

No significant processing problems, such as mixing ability or heat transfer ability, occurred during the SC-5 caustic concentration phase. The sludge was prone to foaming throughout the concentration step. Below is a photograph of the foam, extracted from a video. It is much easier to appreciate the foam by watching the video. 


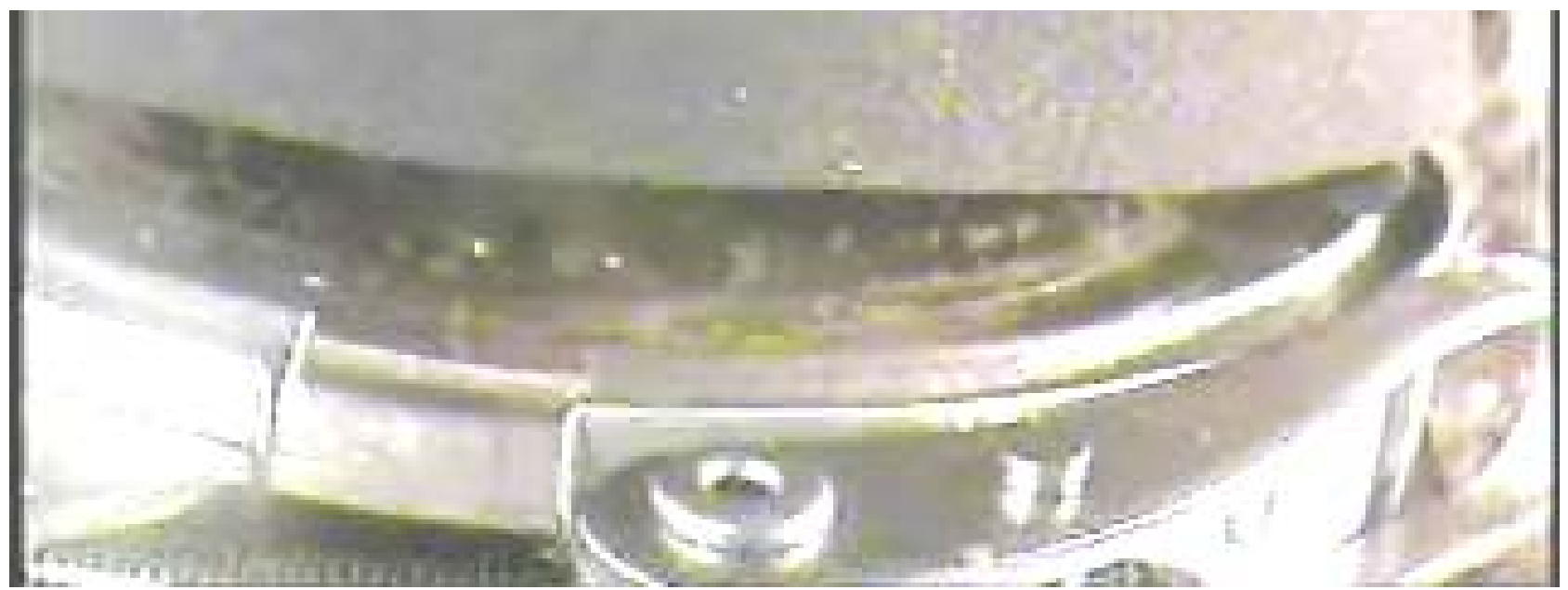

Figure 3-1. Photograph of Persistent Foam during Caustic Concentration

\subsubsection{Caustic Concentration Sample Results (Excluding Noble Metals)}

A sludge receipt sample was pulled at the conclusion of the ARP addition. Many of the elements were measured by Inductively Coupled Plasma - Atomic Emission Spectroscopy (ICP-AES). The results are presented in Table 3-2. The total solids, anions, and mercury analyses were performed. These results are presented in Table 3-3, along with the results of the SC-1 SRAT receipt sample for comparison. In addition, the Tank 40 column was added to predict the concentration of the concentrated sludge prior to ARP addition. This demonstrates that the Tank 40 sludge was very similar to the SB4 Blend used in SC1. Also, the compositions of the SC-1 and SC-5 SRAT receipt samples were very similar. 
Table 3-2. ICP-AES Characterization Results of the SB4 Tank 40 with ARP Product (SC-5 SRAT Receipt) Sample

\begin{tabular}{|c|c|c|c|c|c|c|c|}
\hline \multirow[b]{2}{*}{ Element } & \multirow{2}{*}{$\begin{array}{c}\text { Total } \\
\text { Solids, } \\
\text { Wt \% } \\
\end{array}$} & \multirow{2}{*}{$\begin{array}{l}\text { Std. } \\
\text { Dev. }\end{array}$} & \multirow{2}{*}{$\begin{array}{l}\text { Digestion } \\
\text { Method }\end{array}$} & \multirow[b]{2}{*}{ Element } & $\begin{array}{r}\text { Total } \\
\text { Solids, }\end{array}$ & \multirow[b]{2}{*}{ Std. Dev. } & \multirow{2}{*}{$\begin{array}{l}\text { Digestion } \\
\text { Method }\end{array}$} \\
\hline & & & & & Wt \% & & \\
\hline $\mathrm{Al}$ & 11.5 & 0.218 & $\mathrm{AF}$ & $\mathrm{Ni}$ & 1.11 & 0.0037 & $\mathrm{AR} / \mathrm{AF}$ \\
\hline $\mathrm{Ba}$ & 0.0680 & 0.0029 & $\mathrm{AR} / \mathrm{AF}$ & $\mathrm{P}$ & 0.320 & 0.00922 & AR \\
\hline $\mathrm{Ca}$ & 1.74 & 0.0813 & $\mathrm{AR} / \mathrm{AF}$ & $\mathrm{Pb}$ & $<0.103$ & & $\mathrm{AR}$ \\
\hline $\mathrm{Cd}$ & 0.175 & 0.004 & AR & $\mathrm{S}$ & 2.21 & 0.340 & AR \\
\hline $\mathrm{Ce}^{*}$ & $<0.41$ & NA & AR & $\mathrm{Sb}$ & $<0.198$ & NA & $\mathrm{AF}$ \\
\hline $\mathrm{Cr}$ & 0.0896 & 0.00344 & $\mathrm{AR}$ & $\mathrm{Si}$ & 0.504 & 0.0986 & $\mathrm{AF}$ \\
\hline $\mathrm{Cu}$ & 0.0398 & 0.000731 & $\mathrm{AR}$ & Sn & $<0.589$ & NA & $\mathrm{AF}$ \\
\hline $\mathrm{Fe}$ & 18.8 & 0.567 & $\mathrm{AR} / \mathrm{AF}$ & $\mathrm{Sr}$ & $<0.052$ & NA & $\mathrm{AR} / \mathrm{AF}$ \\
\hline $\mathrm{K}$ & $<1.04$ & NA & AR & $\mathrm{Ti}$ & 1.42 & 0.0150 & $\mathrm{AR}$ \\
\hline $\mathrm{Li}$ & $<0.037$ & NA & AR & $\mathrm{U}$ & 6.12 & 0.116 & $\mathrm{AR}$ \\
\hline $\mathrm{Mg}$ & 1.52 & 0.0491 & $\mathrm{AR} / \mathrm{AF}$ & $\mathrm{V}$ & $<0.129$ & NA & $\mathrm{AF}$ \\
\hline $\mathrm{Mn}$ & 4.15 & 0.111 & $\mathrm{AR} / \mathrm{AF}$ & $\mathrm{Zn}$ & $<0.125$ & 0.000669 & $\mathrm{AF}$ \\
\hline $\mathrm{Na}$ & 14.2 & 0.0751 & $\mathrm{AR}$ & $\mathrm{Zr}$ & 0.083 & 0.040 & $\mathrm{AR}$ \\
\hline
\end{tabular}

Table 3-3. Characterization Results and Acid Calculation Inputs of the SB4 Tank 40 with ARP Product (SC-5 SRAT Receipt) Sample with Comparison to SB4 Blend SRAT Receipt (SC-1) Sample and Tank 40 WAPS Sample ${ }^{5}$

\begin{tabular}{|l|c|c|c|c|}
\hline Measurement & Units & SC-1 & Tank $\mathbf{4 0}^{*}$ & SC-5 \\
\hline Total Solids, & wt\% of slurry & 20.30 & 20.3 & 21.10 \\
\hline Insoluble Solids & wt\% of slurry & 15.23 & 14.91 & 16.22 \\
\hline Soluble Solids & wt\% of slurry & 5.07 & 5.39 & 4.81 \\
\hline Calcined Solids & wt\% of slurry & 15.35 & 15.15 & 15.39 \\
\hline Slurry Density & kg/L slurry & 1.163 & 1.12 & 1.139 \\
\hline Supernate Density & kg/L supernate & 1.045 & 1.048 & 1.071 \\
\hline $\mathrm{Na}$ & wt\% of total solids & 10.8 & 11.0 & 11.0 \\
\hline $\mathrm{Hg}$ & wt\% of total solids & 0.95 & 0.81 & 0.65 \\
\hline Mn & wt\% of calcined solids & 4.345 & 4.26 & 4.380 \\
\hline Nitrite & mg/kg slurry & 16,200 & 16,200 & 14,300 \\
\hline Nitrate & mg/kg slurry & 11,300 & 9,800 & 10,800 \\
\hline Sulfate & mg/kg slurry & $<7,100$ & 1,790 & 2,720 \\
\hline TIC & mg/kg slurry & 1,560 & 1,260 & 2,080 \\
\hline Total Base & mol/L slurry to $\mathrm{pH}=7$ & 0.340 & 0.170 & 0.250 \\
\hline
\end{tabular}

* Calculated data to determine concentration of Tank 40 sample if concentrated to $20.3 \mathrm{wt} \%$ total solids through removal of water by evaporation.

The plan for preparing the SRAT receipt blend was contingent on making additions of sludge and ARP product equivalent to the targets, dewatering to the targets, accurately accounting for expected losses (filling up MWWT and other glassware and tubing that collects condensate), and having no loss of water during evaporation (leak tight vessels and efficient condensers). The measured total solids concentration was $21.1 \mathrm{wt} \%$ versus the $20.3 \mathrm{wt} \%$ target). The assumption in the acid calculation is that the mass of 
slurry was $949.9 \mathrm{~g}$ with slurry analyses as measured (i.e. $21.1 \mathrm{wt} \%$ total solids). If the slurry was overconcentrated by $36 \mathrm{~g}$, leaving $913.9 \mathrm{~g}$, the added acid would have been $4 \%$ higher than target.

There are several analyses that suggest that some chemical changes were taking place in the slurry. First, the total solids were higher than expected, the insoluble solids were higher than expected, and the soluble solids were lower than expected. The first change was mainly due to having less water in the SRAT receipt sample. But the increase in insoluble solids ( 10 g) and decrease in soluble solids ( 10 g) suggests that several soluble species became insoluble during caustic processing. Reviewing the data more closely suggests that the both the soluble nitrite $(\sim 4.2 \mathrm{~g})$ and nitrate $(\sim 1.9 \mathrm{~g})$ mass decreased based on predictions. The only other soluble species above detection limit bases on IC analyses is sulfate, and the prediction and actual mass are within $2 \%$ suggesting only the nitrate and nitrite were involved. Second, the TIC concentration increased by $\sim 0.045 \mathrm{~g}$ carbon or $0.20 \mathrm{~g}$ carbonate. Absorption of carbon dioxide in the caustic sludge would produce sodium carbonate $\left(2 \mathrm{NaOH}+\mathrm{CO}_{2}-\rightarrow \mathrm{Na}_{2} \mathrm{CO}_{3}+\mathrm{H}_{2} \mathrm{O}\right)$. This would increase the TIC concentration, increase the total solids concentration, and decrease the hydroxide concentration. This would increase the total solids concentration by $0.11 \mathrm{~g}$ or $0.05 \mathrm{wt} \%$ total solids. The calculated amount of $\mathrm{CO}_{2}$ absorbed was approximately $72 \%$ of the carbon dioxide present in the air purge during 18 hours of processing.

\subsubsection{Caustic Concentration Sample Results (Noble Metals)}

Since the generation of hydrogen is impacted by the concentration of noble metals and other catalysts in the sludge slurry, the SRAT receipt sample was analyzed using the Inductively Coupled Plasma - Mass Spectroscopy (ICP-MS) for noble metals (Rh, Pd, and Ru) and silver and by ICP-ES for Ti. The SRAT receipt noble metals came from either the SB4 Tank 40 sludge or the ARP product. The SB4 slurry noble metals are well known (see Tank 40 WAPS sample and SC-1 SRAT Receipt columns in Table 3-4). The ARP product noble metals were also analyzed (see ARP Simulant Column in Table 3-4). Adding the expected noble metal compositions from the SB4 sludge and the ARP product yielded a predicted noble metal concentration for the SRAT receipt sample of 3.84E-02 wt \% on a total solids basis for Ru (measured 4.04E-02), 1.86E-02 wt \% on a total solids basis for Rh (measured 2.00E-02), and 3.80E-03 wt \% on a total solids basis for Pd (measured 2.04E-03).

Table 3-4. Concentrations of Noble Metals, Titanium and Silver in wt \% of Total Dried Solids of Sludge, ARP Product and SC-5 SRAT Receipt.

\begin{tabular}{|c|c|c|c|c|c|c|}
\hline Element & HM $^{\text {\% }}$ & $\begin{array}{c}\text { ARP } \\
\text { Simulant }\end{array}$ & $\begin{array}{c}\text { Tank 40H } \\
\text { WAPS } \\
\text { Sample }\end{array}$ & $\begin{array}{c}\text { SC-1 } \\
\text { SRAT } \\
\text { Receipt }^{*}\end{array}$ & $\begin{array}{c}\text { SC-5 SRAT } \\
\text { Receipt }\end{array}$ & $\begin{array}{c}\text { \% Increase } \\
\text { due to ARP } \\
\text { Simulant }\end{array}$ \\
\hline $\mathrm{Ru}$ & $2.17 \mathrm{E}-01$ & $1.04 \mathrm{E}-01$ & $3.12 \mathrm{E}-02$ & $3.48 \mathrm{E}-02$ & $4.04 \mathrm{E}-02$ & 29.4 \\
\hline $\mathrm{Rh}$ & $3.80 \mathrm{E}-02$ & $1.11 \mathrm{E}-01$ & $8.40 \mathrm{E}-03$ & $8.24 \mathrm{E}-03$ & $2.00 \mathrm{E}-02$ & 138 \\
\hline $\mathrm{Pd}$ & $7.90 \mathrm{E}-02$ & $2.71 \mathrm{E}-02$ & $1.25 \mathrm{E}-03$ & $1.32 \mathrm{E}-03$ & $2.04 \mathrm{E}-03$ & 63.2 \\
\hline $\mathrm{Ag}$ & $1.40 \mathrm{E}-02$ & None Added & $9.87 \mathrm{E}-03$ & $9.50 \mathrm{E}-03$ & $8.44 \mathrm{E}-03$ & $-14.5^{\#}$ \\
\hline $\mathrm{Ti}$ & NA & 9.84 & $1.66 \mathrm{E}-02$ & $1.70 \mathrm{E}-02$ & 1.42 & 8,450 \\
\hline
\end{tabular}

$\%$ Bounding noble metals for SRS sludge tanks.

$\wedge$ The sludge used for SC-5 came from the Tank 40 WAPS sample.

* The SC-1 SRAT Receipt sample was not analyzed for noble metals but they were calculated from the measured values of the Tank 40 and Tank 51 blended streams.

\# The ARP simulant is 9.95 wt \% of the total solids, so the Ag concentration should drop by 10\% since no Ag was added in the preparation of the ARP simulant.

The ARP simulant was produced using conservatively high concentrations of noble metals. As a result, the SRAT receipt noble metal concentration was higher than the SB4 sludge or SC-1 SRAT Receipt. For example, the rhodium concentration in the ARP simulant was $97.2 \mathrm{mg} / \mathrm{kg}$ or $1.11 \mathrm{E}-01 \mathrm{wt} \%$ on a total 
solids basis. Recent analyses of the Tanks 41, 25 and 28 salt cake samples have a maximum rhodium concentration of $1.34 \mathrm{mg} / \mathrm{kg}$ in salt cake or $0.64 \mathrm{mg} / \mathrm{kg}$ in a $5.6 \mathrm{M}$ feed to ARP. Thus the Rh in the ARP simulant was approximately 150 times higher than the maximum expected in the first feeds to ARP. At these ARP concentrations, the noble metal concentrations in the SRAT receipt sample would have been lower than the concentration in the sludge sample.

The concentrations of noble metals are important in predicting hydrogen generation, but another important factor is the efficiency of the catalyst. The noble metals that are adsorbed on the surface of the MST, a fine particle, may have a higher catalytic activity than noble metals that are co-precipitated in a mixed metal structure. As a result, the same concentration of noble metal in the ARP simulant might have a higher catalytic activity than the same concentration of noble metal in sludge, which would lead to higher hydrogen generation.

\subsubsection{Caustic Boiling Off-gas Analysis}

Off-gas data for the SC-5 caustic boiling phase are presented Figure 3-2. Based on the results of this testing and previous testing with ARP simulants, very little chemical change occurs during the caustic boiling phase of processing. No significant or prolonged generation of $\mathrm{CO}_{2}, \mathrm{~N}_{2} \mathrm{O}$, or hydrogen was noted. The only change to note during processing was that the hydrogen concentration peaked at the initiation of boiling and slowly decreased while boiling. This is consistent with what has been seen in other Shielded Cells SRAT cycles. Radiolytic hydrogen is constantly being generated in the sludge at a very low generation rate. Some of the hydrogen accumulates in the sludge over time. When boiling is initiated, the hydrogen is released due to the improved mass transfer, and then slowly decreases until it reaches steady state (the solubility of any gas in a liquid goes to zero as the liquid temperature goes to its boiling point). 
WSRC-STI-2008-00130

Revision 0

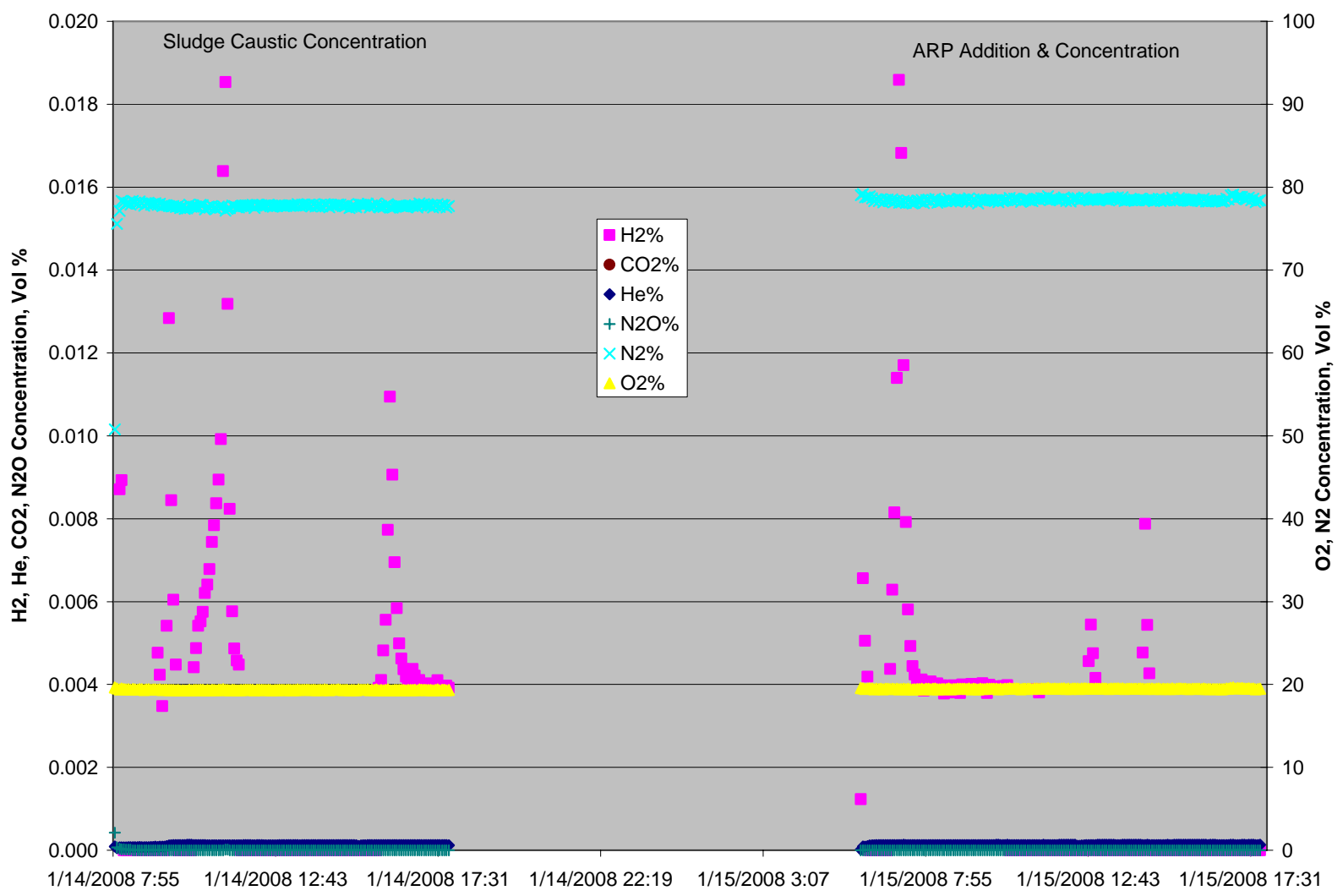

Figure 3-2 Off-gas Concentration during Caustic Concentration and ARP Addition.

\subsection{CPC Processing Results}

The results of the SC-1 and SC-5 are presented here. However, the discussion is primarily focused on the Shielded Cells run, SC-5, with comparisons to SC-1 as warranted.

\subsubsection{SRAT Cycle Acid Calculation}

The key to comparing the SC-5 run with SC-1 was to add the same amount of acid, including the same ratio of nitric and formic acid. If too much acid is added to one of the experiments, then the potential exists for more hydrogen generation due to the presence of additional excess acid rather than to changes in the level of catalytic activity. In that case it is not possible to make an unbiased comparison. There are a number of inputs that impact the acid input, namely the mass of base equivalents, nitrite, manganese, carbonate, and mercury. There are a number of inputs that impact the fraction of formic acid such as predicted nitrite to nitrate destruction, formic acid destruction, nitrite to nitrate conversion and beginning nitrate and formate concentration. Each of these inputs has a different level of accuracy. Therefore extreme care was taken in using three acid stoichiometry equations to try to make sure the acid added in both experiments was nearly identical. 
Table 3-5. Inputs for SC-1 and SC-5 Acid Calculations

\begin{tabular}{|l|c|c|l|}
\hline Acid Calculation Input & SC-1 & SC-5 & Units \\
\hline Fresh Sludge Mass without Trim Chemicals & 954.8 & 949.9 & g slurry \\
\hline Fresh Sludge Weight \% Total Solids & 20.30 & 21.10 & wt\% \\
\hline Fresh Sludge Weight \% Calcined Solids & 15.23 & 16.22 & wt\% \\
\hline Fresh Sludge Weight \% Insoluble Solids & 15.35 & 15.39 & wt\% \\
\hline Fresh Sludge Density & 1.163 & 1.139 & $\mathrm{~kg} / \mathrm{L} \mathrm{slurry}$ \\
\hline Fresh Sludge Nitrite & 16,208 & 14,314 & $\mathrm{mg} / \mathrm{kg}$ slurry \\
\hline Fresh Sludge Nitrate & 11,303 & 10,842 & $\mathrm{mg} / \mathrm{kg}$ slurry \\
\hline Fresh Sludge Oxalate & 0.00 & 0.00 & $\mathrm{mg} / \mathrm{kg}$ slurry \\
\hline Fresh Sludge Formate & 0.00 & 0.00 & $\mathrm{mg} / \mathrm{kg}$ slurry \\
\hline Fresh Sludge Manganese (\% of Calcined Solids) & 4.345 & 4.380 & wt \% calcined basis \\
\hline Fresh Sludge Slurry TIC (treated as Carbonate) & 1,564 & 2,084 & $\mathrm{mg} / \mathrm{kg}$ slurry \\
\hline Fresh Sludge Hydroxide (Base Equivalents) $\mathrm{pH}=7$ & 0.340 & 0.250 & Equiv moles base/L slurry \\
\hline Fresh Sludge Mercury (\% of Total Solids) & 0.9545 & 0.6500 & wt\% dry basis \\
\hline Fresh Sludge Supernate Density & 1.045 & 1.071 & $\mathrm{~kg} / \mathrm{L}$ supernate \\
\hline
\end{tabular}

Table 3-6. Acid Calculation Inputs of the of the SB4 Tank 40 with ARP Product (SC-5 SRAT Receipt) Sample with Comparison to SB4 Blend SRAT Receipt (SC-1) Sample

\begin{tabular}{|c|c|c|c|}
\hline Input/Assumption & SC-1 & SC-5 & Units \\
\hline Conversion of Nitrite to Nitrate in SRAT Cycle & 26.6 & 26.6 & gmol $\mathrm{NO}_{3}{ }^{-} / 100 \mathrm{gmol} \mathrm{NO}$ \\
\hline Destruction of Nitrite in SRAT and SME cycle & 100 & 100 & $\%$ of starting nitrite \\
\hline Destruction of Formic acid charged in SRAT & 7.60 & 7.60 & $\%$ \\
\hline Destruction of oxalate charged & N/A & 50.0 & $\%$ \\
\hline Percent Acid in Excess Stoichiometric Ratio & 130 & 130 & $\%$ \\
\hline SRAT Product Target Solids & 25.00 & 25.08 & $\%$ \\
\hline Predicted or Target REDOX & 0.200 & 0.200 & $\mathrm{Fe}^{+2} / \Sigma \mathrm{Fe}$ \\
\hline $\begin{array}{l}\text { REDOX Equation ( } 7 \text { for } \mathrm{Mn}^{+7} \text {, otherwise assumes } \\
\mathrm{Mn}^{+4} \text { ) }\end{array}$ & 7 & 7 & \\
\hline $\begin{array}{l}\text { Number of basis antifoam additions added during SRAT } \\
\text { cycle }\end{array}$ & 8 & 8 & 100 ppm charges \\
\hline Destruction of Formic acid in SME & 12.7 & 12.7 & $\%$ \\
\hline Destruction of Nitrate in SME & 0.00 & 0.00 & $\%$ \\
\hline Assumed SME density & 1.45 & 1.45 & $\mathrm{~kg} / \mathrm{L}$ \\
\hline No. of basis antifoam additions added during SME cycle & 3 & 3 & $100 \mathrm{ppm}$ charges \\
\hline Sludge Oxide Contribution in SME (Waste Loading) & 35.0 & 30.0 & $\%$ \\
\hline Target SME Solids total Wt\% & 50.0 & 45.0 & $\mathrm{Wt} \%$ \\
\hline
\end{tabular}

An acid calculation was used to determine the amount of nitric and formic acid to add during the SRAT cycle. Based on the SRAT receipt analyses and the acid calculation parameters, both run SC-1 and SC-5 were within $3 \%$ for the moles of acid required, and in both runs the predicted fraction of formic acid to total acid was very similar as shown in Table 3-7. In addition, two supplementary acid predictions were completed to ensure the acid estimate was as accurate as possible. DWPF uses the Hsu acid equation ${ }^{18}$ to predict the acid demand for the experiment. The Hsu equation predicted an acid demand of $1.10 \mathrm{M}$. Since this equation does not include all of the reactions that consume acid, two additional acid equations are being used in simulant experiments to better predict the acid demand. The "Koopman" equation ${ }^{12}$ adds several terms to the Hsu equation and predicted an acid demand of $1.43 \mathrm{M}$ of slurry (131\% of Hsu stoichiometry) for SC-5. The cation ${ }^{19}$ equation predicted an acid demand of $1.56 \mathrm{M}$ for SC-5. The cation 
equation appears to give a reasonable acid addition, however, rather than a minimum required acid addition for its result. The acid requirements for both runs are summarized in Table 3-7. Note there is slightly more nitric acid added in SC-5 due to the lower nitrite and nitrate concentration.

Table 3-7. Required Acid Needed as Predicted by DWPF's Acid Calculation

\begin{tabular}{|c|c|c|}
\hline PARAMETER & SC-1 & SC-5 \\
\hline Hsu 100\% acid, mols/L & 1.13 & 1.10 \\
\hline Koopman Acid Demand, mol/L & 1.44 & 1.43 \\
\hline Cation Acid Demand, mol/L & 1.65 & 1.62 \\
\hline Actual (130\% Hsu) acid added, moles/L & 1.47 & 1.42 \\
\hline Nitric acid, ml & 2.26 & 3.19 \\
\hline Formic acid, ml & 49.91 & 48.93 \\
\hline \% formic & $98.0 \%$ & $97.2 \%$ \\
\hline
\end{tabular}

\subsubsection{SRAT and SME Cycle Processing Observations}

There were no significant processing problems during the SC-5 SRAT cycle other than foaming. There were no difficulties in mixing or heating the sludge slurry. The following SRAT cycle antifoam addition strategy was planned:

- 200 ppm addition prior to starting the cycle

- 100 ppm addition between nitric and formic acid additions

- 500 ppm addition after acid addition, prior to boiling

- 100 ppm addition every 8 hours thereafter

The above strategy is consistent with DWPF's current addition strategy and contains an additional 100 ppm addition (between nitric and formic acid additions) compared to recent antifoam addition strategies for Shielded Cells runs. In the three previous runs containing Tank 51 - SB4, antifoam was needed shortly after formic acid was begun. ${ }^{20,} 21$ It was decided to add the antifoam before it was needed to minimize the chance of a foam-over in this run.

Even with the extra antifoam prior to formic acid addition, an additional $100 \mathrm{ppm}$ of antifoam was needed during the final third of formic acid addition. Also, an extra $100 \mathrm{ppm}$ of antifoam was added with the scheduled antifoam addition eight hours after formic acid addition.

The following SME cycle antifoam addition strategy was planned:

- $100 \mathrm{ppm}$ addition prior to starting the cycle

- 100 ppm addition every 8 hours thereafter

There were significant foaming issues throughout the SC-5 SME cycle. Antifoam was added 7 times, not the 3 additions that were planned. Antifoam was added as often as every hour, and more frequently as the solids concentration reached maximum. However, there were no problems with mixing or achieving the target boil up rates. 


\subsubsection{SRAT and SME Cycle Sample Results}

A slurry sample was pulled from the SRAT vessel at the conclusion of the SRAT cycle. The total solids, anions, and mercury analysis were performed. These results are presented in Table 3-8, along with the results of the SC-1 SRAT cycle for comparison. ${ }^{22}$ As shown in the table, nitrite was adequately destroyed to less than $1,000 \mathrm{mg} / \mathrm{kg}$. Although the mercury was removed to below the DWPF requirement of $0.45 \%$ of total solids, the mercury stripping efficiency was considerably less than that of SC- 1 . This was despite the fact that the, SC-5 SRAT receipt mercury measurement of $0.65 \mathrm{wt} \%$ was significantly lower than the $0.95 \%$ calculated for SC-1. The total solids measurement was lower than the total solids target of 25 wt $\%$.

Table 3-8. SRAT Product Characterization Results

\begin{tabular}{|l|c|c|}
\hline & SC-1 & SC-5 \\
\hline Wt \% Total Solids (slurry basis) & 24.7 & 23.0 \\
\hline Wt \% Insoluble Solids (slurry basis) & 14.7 & 12.8 \\
\hline Wt \% Soluble Solids (slurry basis) & 10.0 & 10.1 \\
\hline Slurry Density (g/mL) & 1.21 & 1.12 \\
\hline Supernate Density (g/mL) & NM & 1.08 \\
\hline Formate (mg/kg slurry) & 44,500 & 39,700 \\
\hline Nitrite (mg/kg slurry) & $<1000$ & $<868$ \\
\hline Nitrate (mg/kg slurry) & 19,300 & 20,900 \\
\hline Mercury (wt \% of total solids) & 0.068 & 0.308 \\
\hline
\end{tabular}

Samples were pulled at the conclusion of the SME cycle and analyzed for total solids, anions, and total organic carbon. Total solids are slightly higher than the target $45 \%$. This is likely due to small water vapor losses from leaks in the off-gas equipment and vessel headspace. Results are given in Table 3-9, along with those from the SC-1 SME Cycle product samples.

Table 3-9. SME Product Weight Percent Solids and Densities

\begin{tabular}{|l|c|c|}
\hline Physical Property & SC-1 & SC-5 \\
\hline Wt \% Total Solids (slurry basis) & 47.6 & 45.6 \\
\hline Wt \% Insoluble Solids (slurry basis) & 38.9 & 38.5 \\
\hline Wt \% Soluble Solids (slurry basis) & 8.7 & 7.1 \\
\hline Slurry Density (g/mL) & 1.40 & 1.40 \\
\hline Supernate Density (g/mL) & 1.09 & 1.09 \\
\hline Formate (mg/kg slurry) & 40,000 & 28,500 \\
\hline Nitrite (mg/kg slurry) & $<1,000$ & $<152$ \\
\hline Nitrate (mg/kg slurry) & 15,300 & 13,300 \\
\hline Total Organic Carbon (mg/kg slurry) & 13,000 & 9,420 \\
\hline
\end{tabular}

\subsubsection{SRAT and SME Cycle Anion Destruction and Conversion}

Inputs to the acid calculation include formate destruction and conversion of nitrite to nitrate. Presented in Table 3-10 and Table 3-11 is a comparison between these assumed values and measured results for the SRAT and SME cycle. As can be seen in the table, nitrite to nitrate conversion was higher than predicted for SC-5 and higher than expected based on the predicted reactions paths (33\% is the expected maximum). This high result is likely due to analytical error or high internal reflux. In both SC-1 and SC-5 the 
formate destruction was much higher than the prediction. During the SME cycle the formate destruction was lower than predicted and the nitrate destruction was higher than predicted for both runs.

Table 3-10. Comparison of Assumed and Measured Anion Destruction and Conversion in the SRAT Cycles

\begin{tabular}{|l|l|c|c|}
\hline & & SC-1 & SC-5 \\
\hline \multirow{2}{*}{ Formate Destruction (\%) } & Assumed & 7.60 & 7.60 \\
\cline { 2 - 4 } & Measured & 24.2 & 28.9 \\
\hline \multirow{2}{*}{ Nitrite Destruction (\%) } & Assumed & 100 & 100 \\
\cline { 2 - 4 } & Measured & $>94.1$ & $>94.1$ \\
\hline \multirow{2}{*}{ Nitrite to Nitrate Conversion (\%) } & Assumed & 26.6 & 26.6 \\
\cline { 2 - 4 } & Measured & 25.0 & 40.8 \\
\hline
\end{tabular}

Table 3-11. Comparison of Assumed and Measured Anion Destruction and Conversion in the SME Cycles

\begin{tabular}{|l|l|c|c|}
\hline & & SC-1 & SC-5 \\
\hline \multirow{2}{*}{ Formate Destruction (\%) } & Assumed & 12.7 & 12.7 \\
\cline { 2 - 4 } & Measured & 0 & -4.3 \\
\hline \multirow{2}{*}{ Nitrate Destruction (\%) } & Assumed & 0 & 0 \\
\cline { 2 - 4 } & Measured & 2.5 & 7.6 \\
\hline
\end{tabular}

\subsubsection{SRAT and SME Cycle Off-gas Analysis (Excluding Hydrogen)}

The nitrous oxide and carbon dioxide off-gas data for the SC-5 SRAT cycle, along with the SC-1 off-gas data, are presented in Figure 3-3 and Figure 3-4. The off-gas data is also summarized in Table 3-12 and Table 3-13. The SRAT cycle off-gas profiles for both nitrous oxide and carbon dioxide are very similar for both SC-1 and SC-5. This is consistent with producing the same quantity of nitrous oxide from nitrite destruction and the same quantity of carbon dioxide from carbonate destruction and mercury and manganese reduction. The carbon dioxide produced from noble metal catalyzed formic acid decomposition is a smaller quantity relative to the carbonate destruction and chemical reduction carbon dioxide peaks. This is consistent with adding the appropriate amount of acid to complete the destruction of nitrite in the SRAT and reduce mercury so that it can be removed by steam stripping to a concentration below $0.45 \mathrm{wt} \%$ total solids. As can be seen from the nitrous oxide figure, the nitrous oxide decreased to near zero earlier in SC-1 than SC-5, suggesting that slightly more excess acid was added in SC-1 than in SC-5. The carbon dioxide generation is higher during the second half of the SRAT cycle and throughout the SME cycle due to the formate destruction resulting from hydrogen generation. Table 3-12 summarizes the carbon dioxide and nitrous oxide generation data for Experiment SC-5 and Table 3-13 summarizes the carbon dioxide and nitrous oxide generation data for Experiment SC-1. 
WSRC-STI-2008-00130

Revision 0

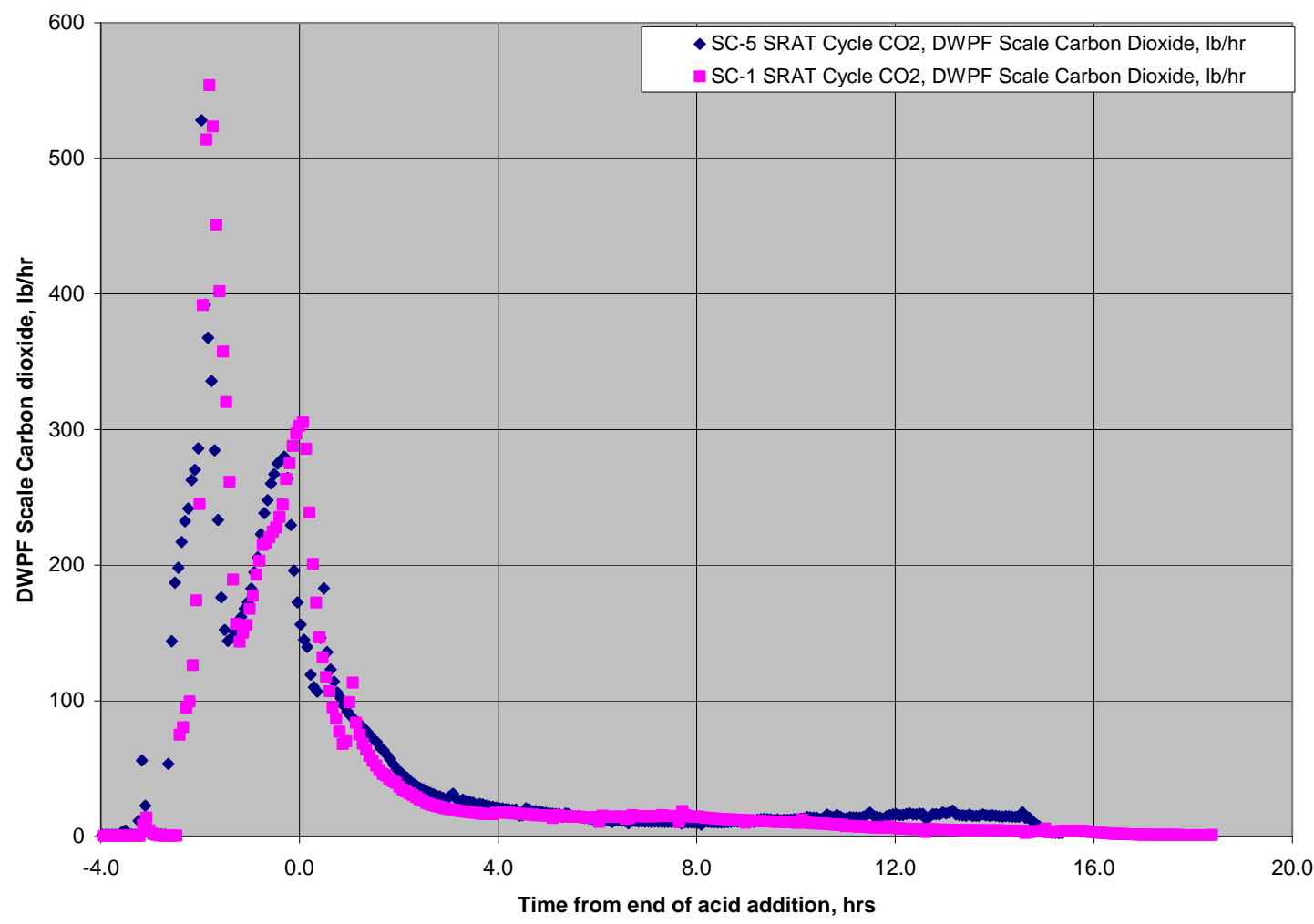

Figure 3-3. Carbon Dioxide Generation during SC-1 and SC-5 SRAT Cycles

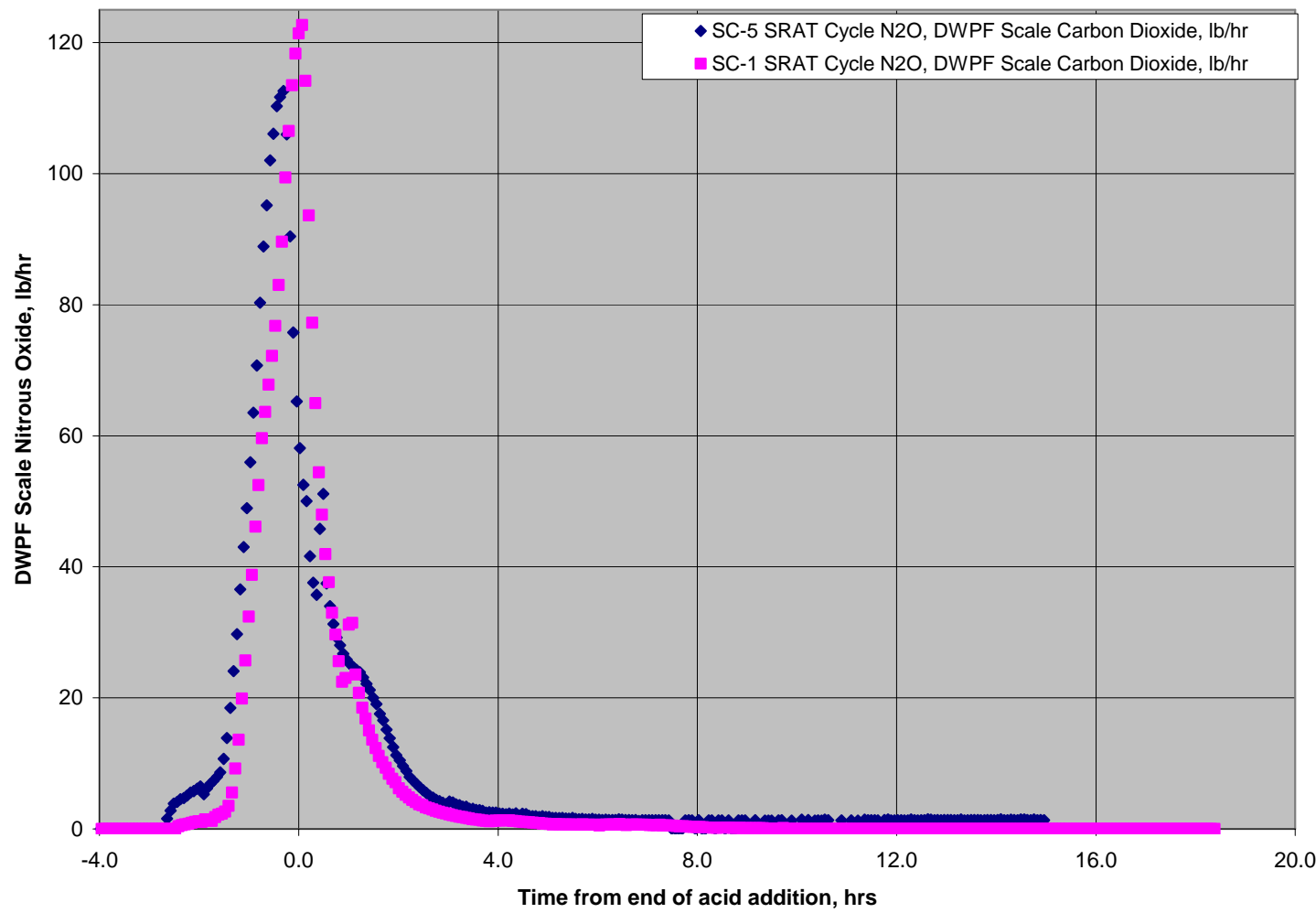

Figure 3-4. Nitrous Oxide Generation during SC-1 and SC-5 SRAT Cycles 
Table 3-12. Maximum Observed Volume Percent and Generation Rates (DWPF Scale) of Hydrogen, Carbon Dioxide, and Nitrous Oxide during the SC-5 SRAT and SME Testing.

\begin{tabular}{|c|c|c|c|c|}
\hline & \multicolumn{2}{|c|}{ SRAT Testing } & \multicolumn{2}{c|}{ SME Testing } \\
\hline \multirow{2}{*}{ Gas } & $\begin{array}{c}\text { Maximum } \\
\text { Observed } \\
\text { Volume \% }\end{array}$ & $\begin{array}{c}\text { Maximum } \\
\text { Gas } \\
\text { Generation } \\
\text { Rate }(\mathrm{lb} / \mathrm{h})\end{array}$ & $\begin{array}{c}\text { Maximum } \\
\text { Observed } \\
\text { Volume \% }\end{array}$ & $\begin{array}{c}\text { Maximum } \\
\text { Gas } \\
\text { Generation } \\
\text { Rate }(\mathrm{lb} / \mathrm{h})\end{array}$ \\
\hline DWPF H Limit & Not Applicable & 0.65 & Not Applicable & 0.223 \\
\hline Hydrogen & 0.0828 & 0.0633 & 0.419 & 0.104 \\
\hline Carbon Dioxide & 25.5 & 528 & 6.23 & 35.6 \\
\hline Nitrous Oxide & 5.77 & 113 & 0.125 & 0.728 \\
\hline
\end{tabular}

Table 3-13. Maximum Observed Volume Percent and Generation Rates (DWPF Scale) of Hydrogen, Carbon Dioxide, and Nitrous Oxide during the SC-1 SRAT and SME Testing.

\begin{tabular}{|c|c|c|c|c|}
\hline & \multicolumn{2}{|c|}{ SRAT Testing } & \multicolumn{2}{c|}{ SME Testing } \\
\hline \multirow{2}{*}{ Gas } & $\begin{array}{c}\text { Maximum } \\
\text { Observed } \\
\text { Volume \% }\end{array}$ & $\begin{array}{c}\text { Maximum } \\
\text { Gas } \\
\text { Generation } \\
\text { Rate (lb/h) }\end{array}$ & $\begin{array}{c}\text { Maximum } \\
\text { Observed } \\
\text { Volume \% }\end{array}$ & $\begin{array}{c}\text { Maximum } \\
\text { Gas } \\
\text { Generation } \\
\text { Rate (lb/h) }\end{array}$ \\
\hline DWPF H2 Limit & Not Applicable & 0.65 & Not Applicable & 0.223 \\
\hline Hydrogen & 0.008 & 0.007 & 0.027 & 0.0078 \\
\hline Carbon Dioxide & 22.7 & 554 & 2.96 & 18.8 \\
\hline Nitrous Oxide & 5.43 & 123 & 0.069 & 0.42 \\
\hline
\end{tabular}

\subsubsection{SRAT and SME Cycle Off-gas Analysis (Hydrogen Only)}

Since hydrogen generation was a prime objective in this experiment, more detailed hydrogen data will be presented. Testing was completed to determine whether the presence of the irradiated ARP simulant containing MST caused uncontrolled or unexpected hydrogen production during experiments simulating the DWPF CPC due to activation of titanium. A concern was raised by an external hydrogen review panel that the alpha loaded MST could act as a catalyst for hydrogen generation (Mar 15, 2007 report, Recommendation 9). ${ }^{1}$ Figure 3-5 graphs the hydrogen concentration for the SRAT cycle and Figure 3-6 for the SME cycle. 
WSRC-STI-2008-00130

Revision 0

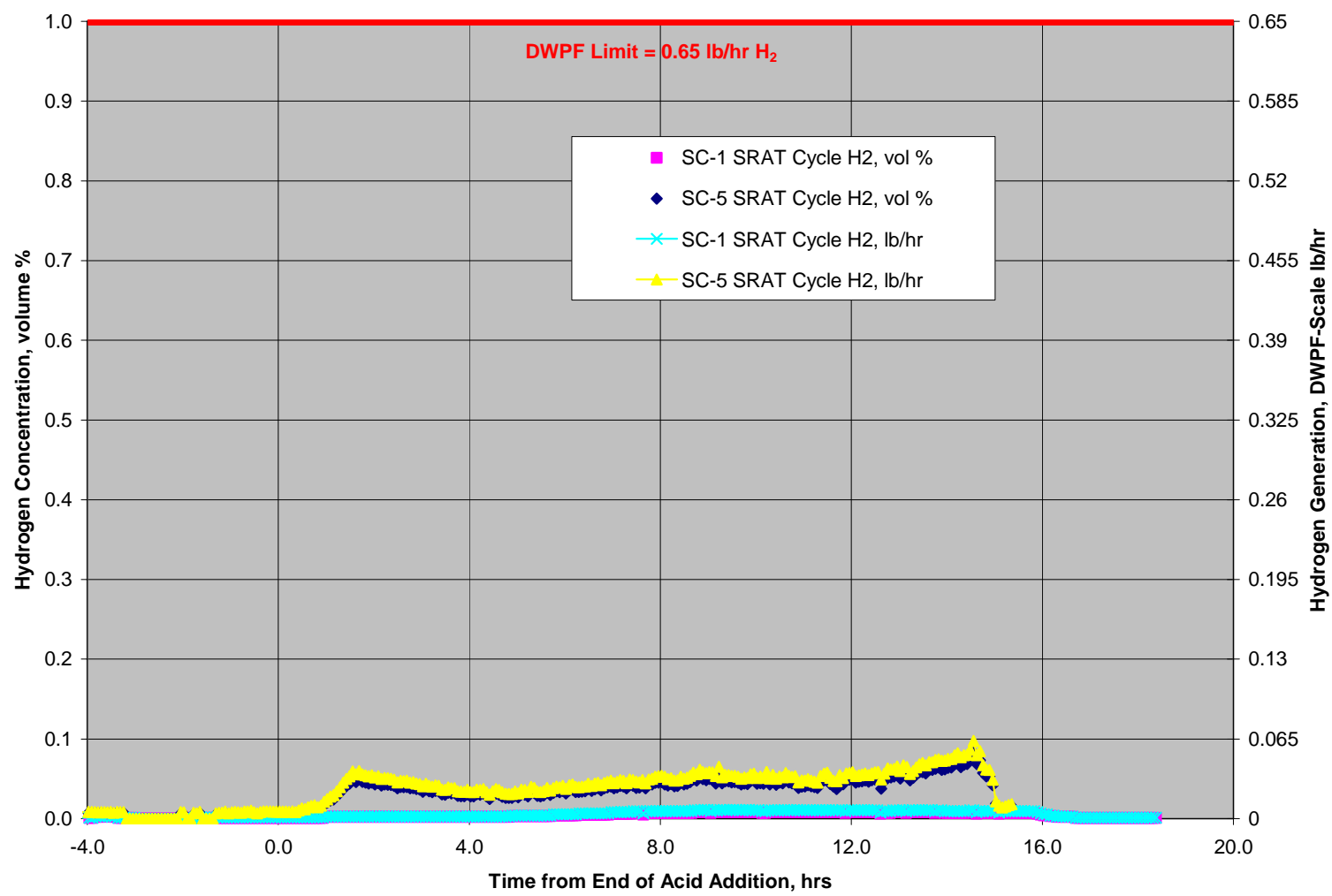

ure 3-5. SRAT Cycle Hydrogen Profile

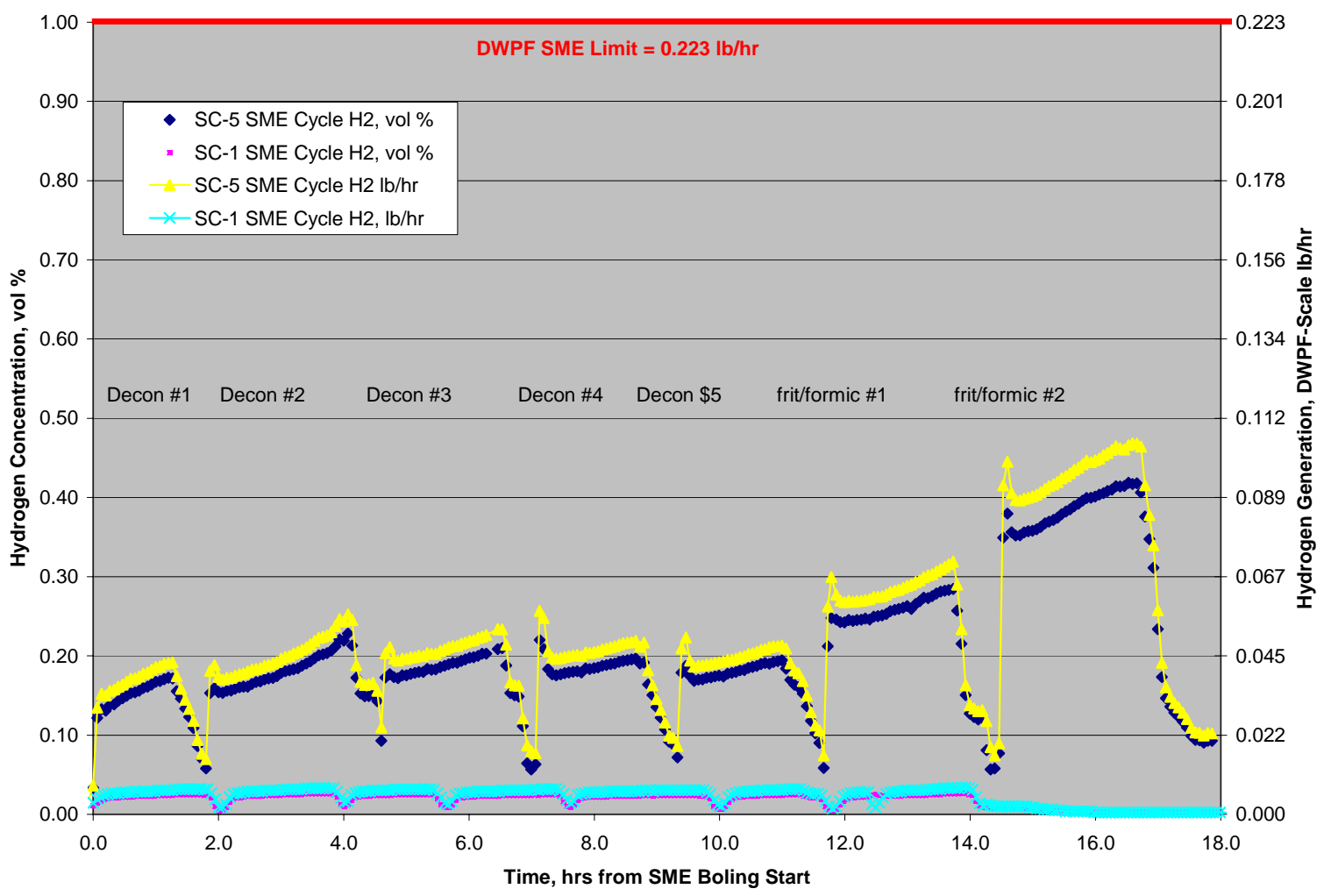

Figure 3-6. SME Cycle Hydrogen Profile 
There are several factors which impact hydrogen generation, namely, noble metal concentration (Rh was 2.4 times more concentrated in SC-5 than SC-1 due to the addition of the ARP simulant), noble metal activity (this is unknown, but the activity of simulant noble metals is typically higher than the activity of noble metals in radioactive sludge ${ }^{23}$ ), formic acid concentration, and temperature. More hydrogen is produced when noble metal concentrations were higher, everything else being equal. ${ }^{23}$ These will all be discussed in more detail below.

Factor 1: Temperature. Based on observations during and after testing, the slurry appeared to be well mixed and the temperature of the slurry was uniform throughout testing. The initial mixing speed was determined by visually observing the slurry mixing. In addition, the vessel was inspected after the experiments and there were virtually no deposits in the vessel. The vessel was rinsed with water, and the glassware was almost pristine. There were no signs of scorching of solids on the glassware, a sign that non-uniform heating was experienced.

Factor 2: Formic acid concentration. The amount of total acid and formic acid added in SC-5 was very similar to SC-1 with respect to the total moles of acid, total moles of formic acid and total moles of nitric added per liter of slurry. The off-gas profiles $\left(\mathrm{N}_{2} \mathrm{O}\right.$ and $\left.\mathrm{CO}_{2}\right)$ were very similar for both SRAT runs. The use of three acid calculation equations was designed to ensure the acid target was correct. The acids were pre-weighed and at the completion of each acid addition, the acid feed line and bottle were flushed twice with DI water to ensure all the planned acid was added. By the completion of the SRAT cycle, SC-5 likely had a lower concentration of free formic acid since $28.9 \%$ of the formic acid was consumed generating hydrogen. The higher hydrogen generation rates were not due to adding excessive formic acid in SC-5.

Factor 3: Noble metal and titanium concentration. The noble metal concentration in SC-5 was higher than in SC-1, due to the conservatively high concentration of $\mathrm{Rh}, \mathrm{Ru}$, and $\mathrm{Pd}$ in the ARP simulant. The noble metal responsible for the maximum hydrogen generation rate is Rh. The Rh concentration in SC-5 was 2.4 times higher than it had been in SC $-1{ }^{23}$ A good control experiment would have had the same concentration of noble metals in SC-5 as SC-1. The Ti concentration was 84.5 times higher in SC-5 than SC-1 due to the addition of the ARP product.

The starting salt solution simulant had a Rh concentration of $>150 \mathrm{x}$ the highest concentration measured in Tanks 25, 28 and $41 .^{24}$ This led to an ARP simulant that was very high in noble metals. By mass balance, only $2 \%$ of the $\mathrm{Rh}, 0.5 \%$ of the $\mathrm{Pd}$, and $2 \%$ of the $\mathrm{Ru}$ added to the original salt solution was present in the ARP simulant. Most of the noble metal present in the ARP simulant was insoluble as 98$99.5 \%$ of the soluble noble metals were removed by washing, necessary to decrease the sodium concentration from 5.6M to $0.5 \mathrm{M}$. The noble metal distribution is summarized in Table 3-14.

Table 3-14. Noble Metals in ARP Product Simulant

\begin{tabular}{|c|c|c|c|}
\hline $\begin{array}{c}\text { NOBLE } \\
\text { METAL }\end{array}$ & $\begin{array}{c}\text { SALT SOLUTION } \\
\text { CONCENTRATION } \\
\text { mg/L }\end{array}$ & $\begin{array}{c}\text { ARP PRODUCT } \\
\text { CONCENTRATION } \\
\text { mg/kg }\end{array}$ & $\begin{array}{c}\text { \% IN ARP } \\
\text { PRODUCT }\end{array}$ \\
\hline $\mathrm{Ru}$ & 100 & 91.2 & 2 \\
\hline $\mathrm{Rh}$ & 100 & 97.2 & 2 \\
\hline $\mathrm{Pd}$ & 100 & 23.7 & 0.5 \\
\hline
\end{tabular}

SB4 simulant testing with added ARP and $\mathrm{MCU}^{25}$ was completed to determine whether decanting up to 100,000 gallons of supernate from Tank 40 would change the SB4 processing or processing window. The ARP product was added with SB-4 levels of noble metals as wt\%'s in the total solids, and no increase in 
hydrogen generation was measured in experiments at $130 \%$ acid stoichiometry compared to tests without ARP. At $170 \%$ acid stoichiometry, the highest hydrogen generation measured was $0.138 \mathrm{lb} / \mathrm{hr}$ in the SRAT Cycle and $0.070 \mathrm{lb} / \mathrm{hr}$ in the SME cycle, significantly lower than measured in SC-5. In previous testing with no increase in noble metals due to the added ARP product, SRAT/ARP processing did not lead to higher hydrogen generation.

Factor 4: Noble metal activity. The noble metal catalytic activity was likely significantly higher in SC-5 than SC-1. The addition of the ARP simulant to SC-5 is responsible for the increase in hydrogen. However, further testing is necessary, due to the fact that a high fraction of noble metals were not fission decay noble metals that had co-precipitated with the other metal nitrates when the acidic waste was neutralized with sodium hydroxide. Instead, a high fraction of the noble metals were added to the salt solution as soluble metal nitrates, then adsorbed on the MST during the simulated ARP processing. This freshly deposited noble metal is likely to offer more surface area, leading to faster dissolution and higher activity catalyst.

Factor 5: New hydrogen generation mechanism. In order to determine whether a new hydrogen generation mechanism, such as the postulated radiolytic activation of titanium to catalyze hydrogen generation, led to the additional hydrogen generation, the above 4 factors would all need to have been controlled in both SC-1 and SC-5. Since factor 3 was not and factor 4 may not have been controlled, the excess hydrogen generation could be due a combination of factors 3, 4, and/or 5. For example, the addition of excessive noble metals and the increased activity of simulant noble metals could together lead to the additional hydrogen generation without a new hydrogen generation mechanism, but the new mechanism can not be ruled out based on this testing.

Hydrogen Conclusion: The hydrogen concentration was significantly higher during the SME cycle in SC-5 than SC-1. The addition of the ARP simulant to SC-5 is responsible for the increase in hydrogen generation. However, further testing is necessary to determine whether a new hydrogen generation mechanism due to radiolytic activation is partially responsible for the higher hydrogen generation or whether it was due to a combination of higher catalyst concentration and/or higher catalyst activity. Repeating the experiment with ARP product having no added noble metals would be needed to determine whether a new hydrogen mechanism is involved. A test with noble metal free ARP simulant should produce less hydrogen than SC-1 since the ARP addition would actually decrease the hydrogen generation as there would be a lower concentration of noble metals in the resultant slurry. Additional testing at higher acid stoichiometries may be needed if differences are still noted. Regardless, SC-5 should hold as a conservative estimate of hydrogen generation.

Although it could not be definitively proved that there was no contribution from hydrogen due to the new hydrogen mechanism, there are two factors that make this unlikely. First, the hydrogen concentration profiles seen in SC-5 are very similar to those expected due to Rh, Ru, and Pd catalysis of formic acid to hydrogen. A new mechanism would lead to a different profile, likely a steady production of hydrogen, instead of the SC-5 peaks and valleys at predictable times based on nitrite destruction, nitrous oxide and carbon dioxide generation. Figure 3-7 compares the hydrogen profile from SC-5 to a simulant run with added $\mathrm{Rh}, \mathrm{Ru}, \mathrm{Pd}, \mathrm{Ag}$ and $\mathrm{Hg}^{26}$ (no added MST). Second, the addition of the ARP product raised the Ti concentration by a factor of 84.5, compared to Tank 40 sludge. Even if the new mechanism does produce hydrogen, it must be much less efficient than the other noble metals. 


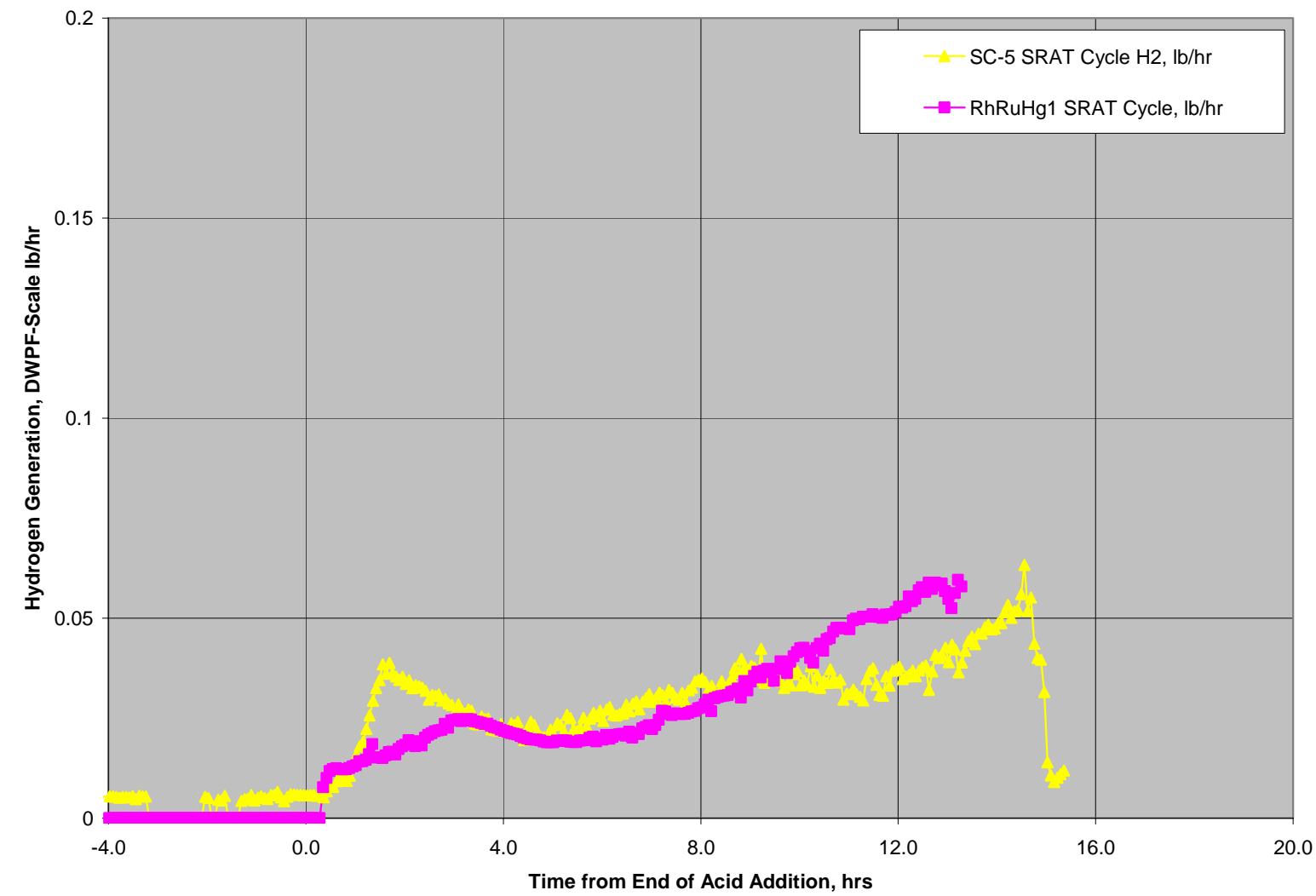

Figure 3-7. Hydrogen Generation Profile Comparison between SC-5 SRAT cycle and Simulant Run RhRuHg1, a SRAT cycle with added Rh, Rh, and Hg, DWPF Scale lb/hr $\mathrm{H}_{2}$

\subsubsection{Metal Solubility during CPC Processing}

In order to determine the metal solubilities in the SRAT receipt, SRAT Product and SME product supernates, samples were submitted to AD for ICP-AES and ICP-MS analyses. The gadolinium (masses 154-158 are stable, with 156 and 158 expected to have the highest concentrations) was lower than the detection limit in the SRAT receipt, SRAT Product and SME product samples. A number of components had high solubilities in the SRAT receipt sample including Group 1A metals (sodium and cesium (133 and 135)), sulfur (sulfate), Group VIB metals (Cr, Mo-95, 97, 98, W-182 and 184), noble metals (Ru 100 and 105, Pd - 106 and 108), and mercury $(196,198,204)$. Note that although $>50 \%$ of the $\mathrm{Ru}$ and $\mathrm{Pd}$ were soluble, very little $\mathrm{Rh}$ was soluble in any of the samples. Note also that the concentration of mercury was very low at the end of the SME cycle as the majority of the mercury was reduced and steam stripped to remove it from the slurry. The raw data for both the ICP-ES and ICP-MS analyses are in Appendix A.

\subsection{Rheology}

Yield stresses and plastic viscosities of three SC-5 samples were measured using the Haake RV-30 viscometer. The three samples included: 1) SC-5 concentrated Tank 40 sludge containing no Actinide Removal Process (ARP) simulant; 2) SC-5 Sludge Receipt and Adjustment Tank (SRAT) receipt material containing ARP simulant; and 3) SC-5 Slurry Mix Evaporator (SME) product from SRAT/SME processing. 
Results of the rheology measurements are given in Table $3-15^{27}$, along with the previously measured weight \% solids and slurry density values or projections. Note that the yield stress and plastic viscosity values in the table are means based upon two independent rheology measurements. Reported along with each mean value is the standard deviation, s, of the two independent measurements. The standard deviation values illustrate that variations for the concentrated sludge and SRAT receipt samples were smaller than for the SME product.

Table 3-15. Yield Stress and Plastic Viscosity Results for SC-5 Samples

\begin{tabular}{|l|l|c|c|c|c|c|}
\hline $\begin{array}{l}\text { SC-5 Sample } \\
\text { Description }\end{array}$ & $\begin{array}{l}\text { Sample } \\
\text { Identifier }\end{array}$ & $\begin{array}{c}\text { Mean } \\
\text { Yield } \\
\text { Stress } \\
(\mathrm{Pa})\end{array}$ & $\begin{array}{c}\text { Mean } \\
\text { Plastic } \\
\text { Viscosity } \\
(\mathrm{cP})\end{array}$ & $\begin{array}{c}\mathrm{Wt} \% \\
\text { Total } \\
\text { Solids }\end{array}$ & $\begin{array}{c}\mathrm{Wt} \% \\
\text { Insoluble } \\
\text { Solids }\end{array}$ & $\begin{array}{c}\text { Slurry } \\
\text { Density } \\
(\mathrm{g} / \mathrm{mL})\end{array}$ \\
\hline \hline $\begin{array}{l}\text { Concentrated } \\
\text { Sludge (w/o ARP) }\end{array}$ & $\begin{array}{l}\text { TS125-07- } \\
\text { A-101327 }\end{array}$ & $\begin{array}{c}4.9 \\
(\mathrm{~s}=0.2)\end{array}$ & $\begin{array}{c}7.0 \\
(\mathrm{~s}=0.2)\end{array}$ & 20.3 & 14.9 & 1.12 \\
\hline $\begin{array}{l}\text { SRAT Receipt } \\
\text { (w/ARP) }\end{array}$ & $\begin{array}{l}\text { TS125-07- } \\
\text { A-101329 }\end{array}$ & $\begin{array}{c}5.3 \\
(\mathrm{~s}=0.06)\end{array}$ & $\begin{array}{c}7.9 \\
(\mathrm{~s}=0.04)\end{array}$ & 21.0 & 15.4 & 1.14 \\
\hline $\begin{array}{l}\text { SME } \\
\text { Product }\end{array}$ & TS125-07- & $\begin{array}{c}4.5 \\
(\mathrm{~s}=0.5)\end{array}$ & $\begin{array}{c}15.1 \\
(\mathrm{~s}=1.7)\end{array}$ & 45.6 & 38.5 & 1.40 \\
\hline
\end{tabular}

A summary of the measurement conditions is given in Table 3-15. Flow curves for the rheology measurements are given in Figures 3-7, 3-8, and 3-9.

Table 3-16. Conditions of Rheology Measurements

\begin{tabular}{|c|c|c|c|c|c|c|}
\hline $\begin{array}{l}\text { SC-5 Sample } \\
\text { Description }\end{array}$ & $\begin{array}{l}\text { Measurement } \\
\text { Date }\end{array}$ & $\begin{array}{c}\text { Sensor } \\
\text { Type }\end{array}$ & Up Ramp & $\begin{array}{c}\text { Holding } \\
\text { Condition } \\
\end{array}$ & $\begin{array}{l}\text { Down } \\
\text { Ramp }\end{array}$ & $\begin{array}{c}\text { Measurement } \\
\text { Temperature }\end{array}$ \\
\hline $\begin{array}{l}\text { Concentrated } \\
\text { Sludge } \\
\text { (w/o ARP) }\end{array}$ & \multirow[t]{2}{*}{ 3/24/08 } & \multirow[t]{2}{*}{ MVI } & \multirow{2}{*}{$\begin{array}{c}0-600 / \mathrm{s} \\
\text { over } \\
5 \mathrm{~min}\end{array}$} & \multirow{2}{*}{$\begin{array}{l}600 / \mathrm{s} \\
\text { for } \\
1 \mathrm{~min}\end{array}$} & \multirow{2}{*}{$\begin{array}{c}600-0 / \mathrm{s} \\
\text { over } \\
5 \mathrm{~min}\end{array}$} & \multirow{3}{*}{$25^{\circ} \mathrm{C}$} \\
\hline $\begin{array}{l}\text { SRAT Receipt } \\
\text { (w/ ARP) }\end{array}$ & & & & & & \\
\hline SME Product & $3 / 25 / 08$ & MVII & $\begin{array}{c}0-300 / \mathrm{s} \\
\text { over } \\
5 \mathrm{~min} \\
\end{array}$ & $\begin{array}{c}300 / \mathrm{s} \\
\text { for } \\
1 \mathrm{~min}\end{array}$ & $\begin{array}{c}300-0 / \mathrm{s} \\
\text { over } \\
5 \mathrm{~min} \\
\end{array}$ & \\
\hline
\end{tabular}



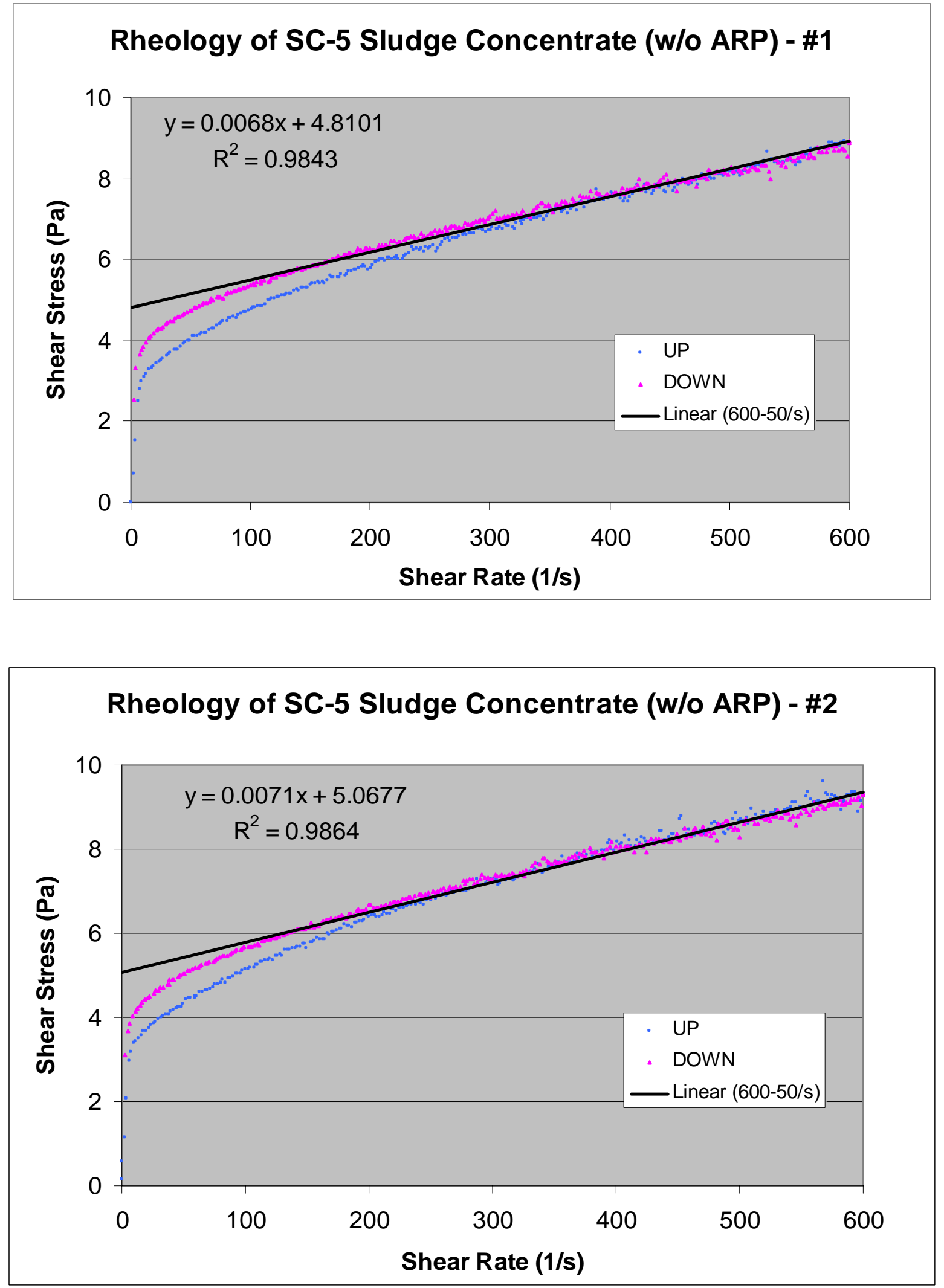

Figure 3-8a and Figure 3-8b. Flow Curves for SC-5 Sludge Concentrate Sample (w/o/ ARP) 

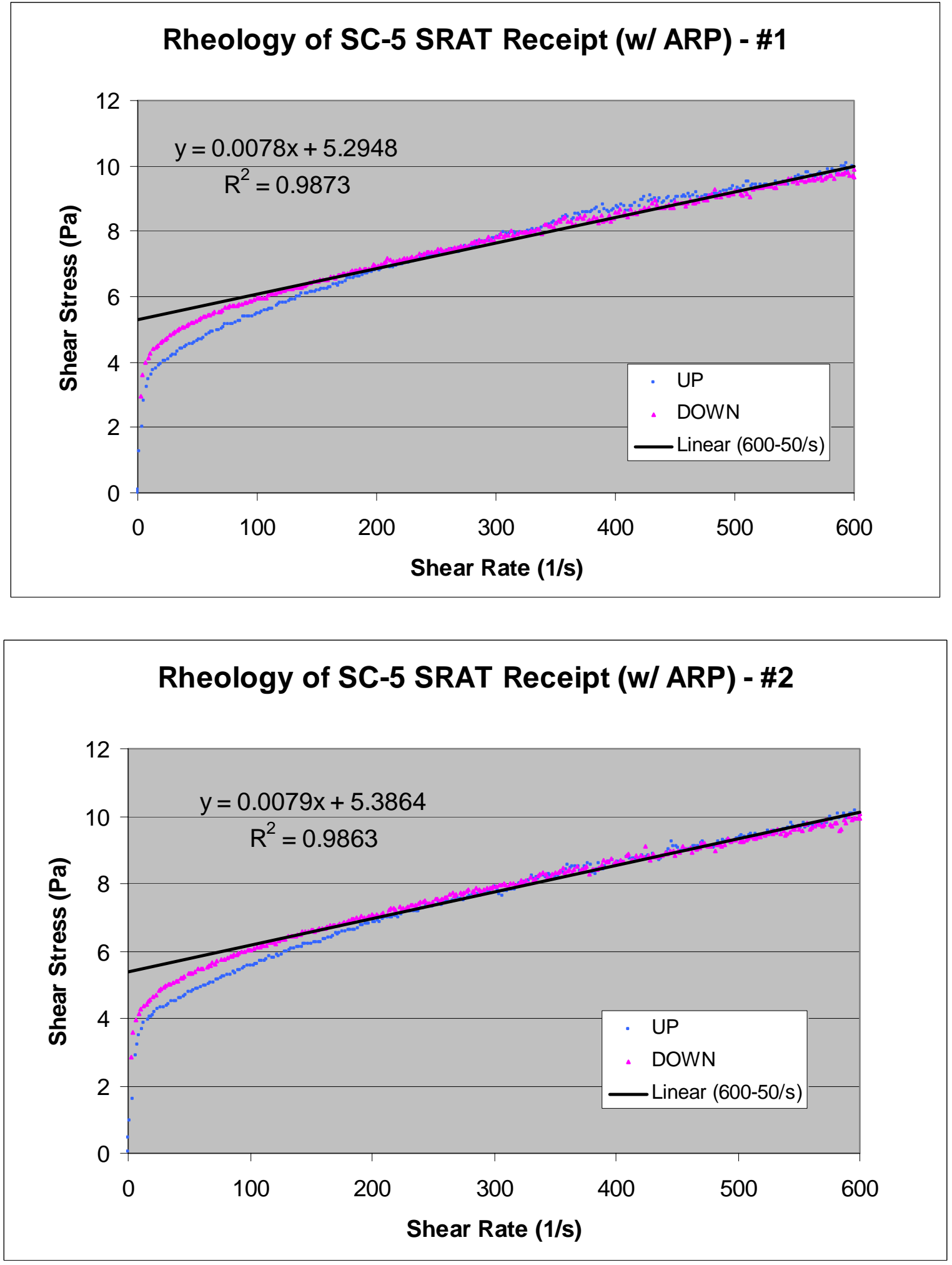

Figure 3-9a and Figure 3-9b. Flow Curves for SC-5 SRAT Receipt Sample (w/ ARP) 

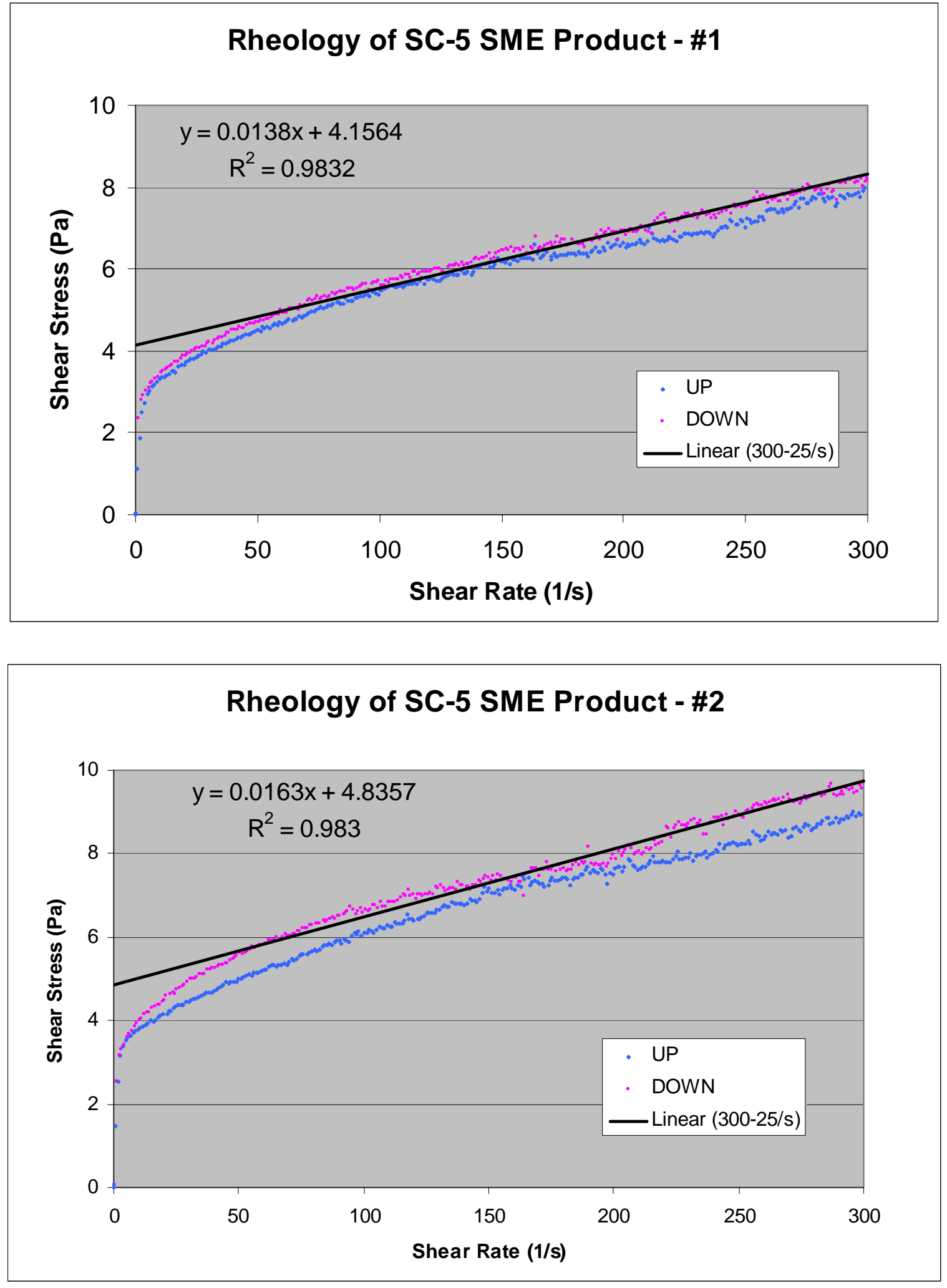

Figure 3-10a and Figure 3-10b. Flow Curves for SC-5 SME Product Sample 


\subsection{CONCLUSIONS}

Shielded Cells Run SC-5 involving caustic sludge concentration, ARP Addition, SRAT and SME cycles were completed as planned. This was the first DWPF demonstration in the cells with added ARP simulant. The main objective for the run was the determination of hydrogen generation. The acid addition strategy used, however, was a conservative one for SB4 equivalent to about $130 \%$ acid stoichiometry. Although $130 \%$ is at the low end of the recommended range (130-170\%) for this sludge batch, it is also DWPF's processing target. Attempts to go to higher acid stoichiometry should be approached in small-step changes (i.e. 5\% increases) when ARP is present. Summary results are listed below.

- The caustic sludge concentration and ARP addition phases were both completed with only foaming noted as a significant processing issue. SC-5 used the DWPF antifoam strategy of $200 \mathrm{ppm}$ antifoam prior to processing and $200 \mathrm{ppm}$ each four hours. There were no foam-overs, although foam was persistent throughout processing. Additions of antifoam demonstrated that Antifoam 747 was effective in controlling foam. Minimal chemical reactions were occurring during the caustic sludge concentration and ARP Addition phases of processing, based on off-gas analyses. However, there apparently was a decrease in soluble nitrite and nitrate, likely due to sorption on the noble metals or MST or due to analytical error.

- The SRAT cycle hydrogen generation rate, scaled to a 6000 gallon batch, peaked at $0.0633 \mathrm{lb} \mathrm{H}_{2} / \mathrm{hr}$, well below the DWPF limit of $0.65 \mathrm{lb} \mathrm{H}_{2} / \mathrm{hr}$ but higher than seen in the comparable SC-1 run without ARP. The hydrogen concentration was still climbing at the end of the SRAT cycle, not the typical peak seen during SRAT processing. One processing note is that foam was evident throughout processing, but was less persistent than the SME cycle. Two additional $100 \mathrm{ppm}$ antifoam additions were made to control foam during formic acid addition and midway through reflux. The nitrite concentration was less than the $1000 \mathrm{mg} / \mathrm{kg}$ and the mercury concentration was less than $0.45 \mathrm{wt} \%$ mercury, meeting DWPF processing limits.

- The SME cycle hydrogen generation rate, scaled to a 6000 gallon batch, peaked at $0.104 \mathrm{lb} \mathrm{H}_{2} / \mathrm{hr}$, below the DWPF limit of $0.223 \mathrm{lb} \mathrm{H}_{2}$ /hr but significantly higher than seen during the SC- 1 run. The hydrogen concentration was still climbing at the end of the SME cycle, not the typical peak seen during SME processing with simulants, although this behavior has been seen in some Shielded Cells experiments since SB3. Seven 100 ppm antifoam additions were made, four more than planned (100 ppm prior to initial heatup and 100 ppm added each 8 hours during boiling).

- The addition of the ARP simulant to SC-5 was responsible for the increase in hydrogen. However, further testing is necessary to determine whether a new hydrogen generation mechanism is partially responsible for the higher hydrogen generation or whether it was merely a combination of higher catalyst concentration and/or higher catalyst activity. It is possible that an overestimation of the SRAT receipt mass by $36 \mathrm{~g}$ led to an over-addition of acid by $4 \%$ (135\% acid stoichiometry). This could have also contributed to increased hydrogen generation rates compared to SC- 1 . The $\mathrm{H}_{2}$ generation rate profile does not look that different from a test without any added MST, so there is no evidence for a new mechanism of $\mathrm{H}_{2}$ generation due to the added Ti from MST in the SC-5 data.

This experiment was conservative for hydrogen generation compared to planned ARP and SWPF processing. SB4 sludge is high in noble metals relative to previous sludge batches. The ARP simulant was higher in all noble metals than the sludge. It is expected this experiment will bound future processing under nominal processing conditions. 


\subsection{RECOMMENDATIONS}

The testing demonstrated that hydrogen generation rate was below DWPF's operating limits with irradiated ARP simulant. Based on what is known about hydrogen generation from typical SRNL testing, hydrogen generation behavior in the SC-5 test appears to be consistent with previous simulant and radioactive slurry behavior. As resources permit, further testing could be performed to more clearly understand any changes in behavior that are associated solely with the inclusion of MST or the ARP process itself. To accomplish this goal, the following path forward could be implemented:

1. Repeat experiment SC-5 with ARP product containing irradiated MST but having no added noble metals. If MST is the catalytic source, then a test with noble metal free ARP simulant should produce similar hydrogen to the SC-5 run.

2. Perform testing with simulants to determine the efficiency of MST sorbed noble metals compared to noble metals added to the ARP product. This test would provide data to indicate whether MST is more efficient at sorbing soluble noble metals from the salt solution, forming a more active noble metal.

3. Transfer a sample of the actual ARP product from DWPF to SRNL to perform testing against a run without ARP. This will mitigate any potential differences caused by simulant fabrication.

To ensure that bounding levels of ARP noble metals have been considered,, future feeds for both ARP and SWPF should be analyzed for Pd, Rh, and Ru since high concentrations of these noble metals in ARP and SWPF will likely lead to higher hydrogen generation in DWPF CPC processing. Presently, only Pd is reported by SRNL for salt solutions, although all 3 noble metal could be estimated based on the ICPMS results. 


\subsection{REFERENCES}

1. $\quad$ Plodinec, M. J. Report of Hydrogen Generation Review Panel; 3-15-2007.

2. Wiemers, C. D.; Anderson, C. A.; Petersen, M. E. Evaluation of Process OffGases Released During the Formating of an HWVP Feed Simulant; Pacific Northwest Lab: Richland, WA, 1987.

3. Bickford, D. F.; Coleman, C. J.; Hsu, C.-L. W.; Eibling, R. E. Control of High Level Radioactive Waste-Glass Melters - Part 6: Noble Metal Catalyzed Formic Acid Decomposition, and Formic Acid/Denitration; Savannah River Laboratory: Aiken, South Carolina 29808.

4. Walker, D. D., Bibler, N. E., The Dependence on Radiolytic $\mathrm{H}_{2}$ Generation of the Nitrate Concentration in High-level Solutions; Savannah River Laboratory: Aiken, SC, 11-19-1991.

5. Bannochie, C. J. Tank 40 Final SB4 Chemical Characterization Results; Savannah River National Laboratory: Aiken, SC 29808, January 2008.

6. Lambert, D. P. Perform Testing on Irradiated ARP Simulant in Shielded Cells to Determine Impact of MST on SRAT and SME Hydrogen Generation; Savannah River National Laboratory: 10-292007.

7. $\quad$ Bannochie, C. J., Lambert, D. P., Reboul, S. H. Analytical Sample Support Matrix for ARP SB4 SRAT/SME Testing in the Shielded Cells; January 14, 2008.

8. Analytical Development Procedures Manual; Savannah River National Laboratory: Aiken, SC, 2008.

9. $\quad$ Process Science and Engineering Section Procedure Manual; Savannah River National Lab: Aiken, SC, 2008.

10. Bartling, K. Salt Waste Processing Facility Project Mass Balance Model Summary Deliverable: $2.4 ; 10 / 04 / 2007$.

11. Subosits, S. G. Actinide Removal Process (ARP) Facility; September 2004.

12. Koopman, D. C. Preparation, Characterization, and Preliminary SRAT/SME Testing of a Simulant for the Hydrogen and Rheology Modifier Programs; Savannah River National Lab: Aiken, SC, September 11, 2007.

13. Stone, M. E. Lab-Scale CPC Equipment Set-up; Savannah River National Lab: 2006.

14. Stone, M. E. SRAT Assembly for SB4 Shielded Cells Testing: SC-5; Savannah River National Lab: January 11, 2008.

15. Lambert, D. P. Acid Calculation Spreadsheet for DWPF Simulations; Savannah River National Laboratory: Aiken, SC, 2006.

16. Lambert, D. P. SC-5 Notebook; Savannah River National Laboratory: Aiken, SC, 2008.

17. Darby, R., Chemical Engineering Fluid Mechanics, 2nd edition. Marcel Dekker: 2001. 
18. Hsu, C. W. DWPF Formic Acid Requirement; July 5, 1990.

19. Koopman, D. C. Al in Supernate in Cation Acid Calc (E-mail to D. P. Lambert) Savannah River National Laboratory: Aiken, SC, December 13, 2007.

20. Koopman, D. C.; Pareizs, J. M.; Lambert, D. P.; Bannochie, C. J. Sludge Batch 4 Follow-up Qualification Studies to Evaluate Hydrogen Generation; Technical Report WSRC-STI-2007-00212; Savannah River National Laboratory: Aiken, SC, 2007.

21. Pareizs, J. M.; Bannochie, C. J.; Barnes, M. J.; Bibler, N. E.; Click, D. R.; Hansen, E. K.; Lambert, D. P.; Stone, M. E. Demonstration of the DWPF Flowsheet in the SRNL Shielded Cells in Support of Sludge Batch 4 Qualification; Technical Report WSRC-STI-2007-00053; Savannah River National Laboratory: Aiken, SC, 2007.

22. $\quad$ Pareizs, J. M.; Barnes, M. J.; Lambert, D. P.; Stone, M. E.; Hansen, E. K.; Click, D. R. Summary of Test Parameters and Data from the Shielded Cells Demonstration of Sludge Batch 3/4 Blend SC-1 (70/30) SRAT and SME Cycle; Savannah River National Lab: Aiken, SC, 12-19-2006.

23. Koopman, D. C.; Herman, C. C. Noble Metal Catalyzed H2 generation in the Defense Waste Processing Facility; December 6, 2006.

24. Martino, C. Tank 25 saltcake spreadsheet; 3-10-2008.

25. Koopman, D. C.; Best, D. R.; Williams, M. F. Impact of SB4 Tank 40 Decant and ARP/MCU Additions with/without Added Caustic on DWPF CPC Performance; Savannah River National Lab: April 2008.

26. Koopman, D. C.; Edwards, T. B. Catalytic Interactions of $\mathrm{Rh}, \mathrm{Ru}$, and $\mathrm{Hg}$ during Simulated DWPF CPC Processing with Hydrogen Generation; Savannah River National Lab: Aiken, SC, Draft.

27. Reboul, S. H. Rheology of SC-5 Samples; Savannah River National Lab: Aiken, SC, April 3, 2008. 


\subsection{ACKNOWLEDGEMENTS}

The authors would like to recognize the invaluable support of the SRNL Shielded Cells technicians and management for the in-Cells work (Jane Howard, Mona Galloway, Nan Stanley, Lucy Beasly) and the ACTL technicians (Jon Duvall, Phyllis Workman, Irene Reamer and Vickie Williams) for assistance in equipment setup, reagent preparation, in-cell analyses and consultation during the SRAT and SME cycles. Their capable support of the around-the-clock testing is greatly appreciated.

Kim Wyszynski, Mona Blume, David Herman and Chris Beam were responsible for the preparation of the ARP simulant used during the testing.

Kathy White, Tom White, Curtis Johnson, Mark Jones, Elaine Pearson, and Leigh Brown of AD capably managed and analyzed the radioactive samples generated during this experiment. David Best, Whitney Thomas, and Pat Toole completed the analyses for the nonradioactive samples. We especially appreciated the short turn-around time for the analyses required for the acid calculation. 


\section{APPENDIX A. SRAT RECEIPT, SRAT PRODUCT AND SME PRODUCT ICP-ES AND ICP-MS SAMPLE RESULTS}

Table A-1: SRAT Receipt, SRAT Product and SME Product ICP-ES Sample Results

\begin{tabular}{|c|c|c|c|c|c|c|c|c|}
\hline Element & $\begin{array}{c}\text { SRAT } \\
\text { Receipt } \\
\text { Slurry, } \\
\text { wt \% }\end{array}$ & $\begin{array}{c}\text { SRAT } \\
\text { Receipt } \\
\text { Supernate, } \\
\text { mg/kg }\end{array}$ & $\begin{array}{c}\text { SRAT } \\
\text { Product } \\
\text { Supernate, } \\
\mathrm{mg} / \mathrm{kg}\end{array}$ & $\begin{array}{c}\text { SME } \\
\text { Product } \\
\text { Supernate, } \\
\mathrm{mg} / \mathrm{kg}\end{array}$ & $\begin{array}{c}\text { SRAT } \\
\text { Receipt } \\
\text { supernate, } \\
\text { wt } \%\end{array}$ & $\begin{array}{c}\text { SRAT } \\
\text { Product } \\
\text { supernate, } \\
\text { wt } \%\end{array}$ & $\begin{array}{c}\text { SME } \\
\text { Product } \\
\text { supernate, } \\
\text { wt } \%\end{array}$ & $\begin{array}{c}\% \\
\text { soluble }\end{array}$ \\
\hline \multicolumn{9}{|l|}{$\mathrm{Ag}$} \\
\hline $\mathrm{Al}$ & 11.00 & 633.8 & & & 0.36 & & & 3.3 \\
\hline$B$ & & 10.3 & 1.7 & 22.3 & 0.01 & 0.00 & 0.01 & \\
\hline $\mathrm{Ba}$ & 0.07 & & & & & & & \\
\hline \multicolumn{9}{|l|}{$\mathrm{Be}$} \\
\hline $\mathrm{Ca}$ & 1.84 & 19.7 & $1,577.5$ & $1,546.7$ & 0.01 & 0.79 & 0.55 & 0.6 \\
\hline $\mathrm{Cd}$ & 0.18 & & 20.8 & 17.2 & & 0.01 & 0.01 & \\
\hline \multicolumn{9}{|l|}{$\mathrm{Ce}$} \\
\hline $\mathrm{Cr}$ & 0.09 & 38.6 & & & 0.02 & & & 24.4 \\
\hline $\mathrm{Cu}$ & 0.04 & & & & & & & \\
\hline $\mathrm{Fe}$ & 19.71 & 6.7 & & 11.9 & 0.00 & & 0.00 & 0.0 \\
\hline \multicolumn{9}{|l|}{$\mathrm{Gd}$} \\
\hline K & & & 265.0 & & & 0.13 & & \\
\hline \multicolumn{9}{|l|}{$\mathrm{La}$} \\
\hline $\mathrm{Li}$ & & & 14.8 & 187.0 & & 0.01 & 0.07 & \\
\hline $\mathrm{Mg}$ & 1.60 & 4.4 & $1,717.5$ & $1,374.0$ & 0.00 & 0.86 & 0.49 & 0.2 \\
\hline $\mathrm{Mn}$ & 4.38 & & $2,642.5$ & $2,980.0$ & & 1.32 & 1.06 & \\
\hline \multicolumn{9}{|l|}{ Mo } \\
\hline $\mathrm{Na}$ & 14.24 & 23,150 & 27,2 & $29,400.0$ & 13.14 & 13.59 & 10.48 & 92.2 \\
\hline $\mathrm{Ni}$ & 1.11 & & & & & & & \\
\hline $\mathrm{P}$ & 0.32 & & & & & & & \\
\hline \multicolumn{9}{|l|}{$\mathrm{Pb}$} \\
\hline $\mathrm{S}$ & 2.21 & $1,048$. & 845.8 & 908.7 & 0.59 & 0.42 & 0.32 & 26.9 \\
\hline \multicolumn{9}{|l|}{$\mathrm{Sb}$} \\
\hline $\mathrm{Si}$ & 0.50 & & 35.5 & & & 0.02 & & \\
\hline \multicolumn{9}{|l|}{ Sn } \\
\hline $\mathrm{Sr}$ & & & 14.6 & 15.9 & & 0.01 & 0.01 & \\
\hline $\mathrm{Ti}$ & 1.42 & & & & & & & \\
\hline$U$ & 6.12 & & & & & & & \\
\hline \multicolumn{9}{|l|}{$\mathrm{V}$} \\
\hline \multicolumn{9}{|l|}{$\mathrm{Zn}$} \\
\hline $\mathrm{Zr}$ & 0.08 & & & & & & & \\
\hline
\end{tabular}


WSRC-STI-2008-00130

Revision 0

Table A-2: SRAT Receipt, SRAT Product and SME Product ICP-MS Sample Results, mg/kg

\begin{tabular}{|c|c|c|c|c|c|c|c|}
\hline \multirow[t]{2}{*}{ Mass\# } & \multirow{2}{*}{$\begin{array}{l}\text { Sludge } \\
\text { SRAT } \\
\text { Receipt }\end{array}$} & \multicolumn{3}{|c|}{ Supernate, $\mathrm{mg} / \mathrm{kg}$} & \multicolumn{3}{|c|}{ Supernate Slurry Basis. mg/kg } \\
\hline & & $\begin{array}{c}\text { SRAT } \\
\text { Receipt }\end{array}$ & $\begin{array}{c}\text { SRAT } \\
\text { Product }\end{array}$ & $\begin{array}{c}\text { SME } \\
\text { Product }\end{array}$ & $\begin{array}{c}\text { SRAT } \\
\text { Receipt }\end{array}$ & $\begin{array}{c}\text { SRAT } \\
\text { Product }\end{array}$ & $\begin{array}{c}\text { SME } \\
\text { Product }\end{array}$ \\
\hline 85 & 10.8 & 0.086 & 0.104 & & 0.072 & 0.091 & \\
\hline 86 & 8.5 & & 11.883 & 13.650 & & 10.362 & 8.395 \\
\hline 87 & 10.6 & 2.889 & 12.407 & 13.332 & 2.420 & 10.819 & 8.199 \\
\hline 88 & 143.5 & 0.939 & 227.824 & 234.685 & 0.787 & 198.662 & 144.331 \\
\hline 89 & 117.0 & & & & & & \\
\hline 90 & 141.0 & & 84.687 & 84.897 & & 73.847 & 52.212 \\
\hline 91 & 119.6 & & & & & & \\
\hline 92 & 115.8 & 1.573 & & & 1.318 & & \\
\hline 93 & 133.8 & & & & & & \\
\hline 94 & 130.1 & 0.976 & & & 0.818 & & \\
\hline 95 & 6.5 & 9.368 & & 0.221 & 7.848 & & 0.136 \\
\hline 96 & 141.5 & 2.012 & & & 1.686 & & \\
\hline 97 & 2.8 & 8.220 & 1.247 & & 6.886 & 1.088 & \\
\hline 98 & 5.7 & 9.723 & 0.480 & & 8.146 & 0.419 & \\
\hline 99 & 24.7 & 11.403 & 1.430 & & 9.553 & 1.247 & \\
\hline 100 & 21.7 & 8.801 & 2.411 & & 7.373 & 2.103 & \\
\hline 101 & 154.8 & & 3.505 & 9.512 & & 3.057 & 5.850 \\
\hline 102 & 155.0 & 0.519 & 4.183 & 10.012 & 0.435 & 3.647 & 6.157 \\
\hline 103 & 200.3 & 3.188 & 10.272 & 10.463 & 2.671 & 8.957 & 6.435 \\
\hline 104 & 94.3 & 2.633 & 2.529 & 3.045 & 2.206 & 2.205 & 1.873 \\
\hline 105 & 12.4 & 7.005 & & & 5.869 & & \\
\hline 106 & 30.7 & 8.182 & 4.300 & 3.536 & 6.855 & 3.750 & 2.175 \\
\hline 107 & 44.4 & 0.978 & & & 0.819 & & \\
\hline 108 & 18.0 & 7.319 & 3.992 & 3.075 & 6.132 & 3.481 & 1.891 \\
\hline 109 & 41.9 & & 0.243 & & & 0.212 & \\
\hline 110 & 141.5 & 3.600 & 50.992 & 38.516 & 3.016 & 44.465 & 23.687 \\
\hline 111 & 168.3 & & 57.320 & 46.060 & & 49.983 & 28.327 \\
\hline 112 & 310.3 & & 113.678 & 89.163 & & 99.127 & 54.835 \\
\hline 113 & 228.0 & & 69.666 & 62.466 & & 60.748 & 38.417 \\
\hline 114 & 375.3 & & 137.906 & 105.552 & & 120.254 & 64.914 \\
\hline 116 & 85.7 & & 28.273 & 22.586 & & 24.654 & 13.890 \\
\hline 117 & 1.6 & & 0.301 & & & 0.262 & \\
\hline 118 & 4.8 & & 0.942 & & & 0.822 & \\
\hline 119 & 329.0 & & 5.378 & 0.573 & & 4.690 & 0.352 \\
\hline 120 & 4.2 & & 1.254 & & & 1.094 & \\
\hline 121 & 2.8 & & & & & & \\
\hline 122 & 1.1 & & 0.231 & & & 0.202 & \\
\hline 123 & 2.0 & & & & & & \\
\hline 124 & 1.8 & & 0.312 & & & 0.272 & \\
\hline 125 & 2.3 & & & & & & \\
\hline 126 & & & & & & & \\
\hline 128 & 16.4 & & & & & & \\
\hline 130 & 80.7 & & & & & & \\
\hline 133 & 11.9 & 8.611 & 16.389 & 21.980 & 7.214 & 14.291 & 13.518 \\
\hline
\end{tabular}


WSRC-STI-2008-00130

Revision 0

\begin{tabular}{|c|c|c|c|c|c|c|c|}
\hline \multirow[t]{2}{*}{ Mass\# } & \multirow{2}{*}{$\begin{array}{l}\text { Sludge } \\
\text { SRAT } \\
\text { Receipt }\end{array}$} & \multicolumn{3}{|c|}{ Supernate, mg/kg } & \multicolumn{3}{|c|}{ Supernate Slurry Basis. mg/kg } \\
\hline & & $\begin{array}{c}\text { SRAT } \\
\text { Receipt }\end{array}$ & $\begin{array}{c}\text { SRAT } \\
\text { Product }\end{array}$ & $\begin{array}{c}\text { SME } \\
\text { Product }\end{array}$ & $\begin{array}{c}\text { SRAT } \\
\text { Receipt }\end{array}$ & $\begin{array}{c}\text { SRAT } \\
\text { Product }\end{array}$ & $\begin{array}{c}\text { SME } \\
\text { Product }\end{array}$ \\
\hline 134 & 49.9 & & & & & & \\
\hline 135 & 7.8 & 1.258 & 2.493 & 3.494 & 1.054 & 2.174 & 2.149 \\
\hline 136 & 9.1 & & & & & & \\
\hline 137 & 96.5 & 3.458 & 8.217 & 11.388 & 2.897 & 7.165 & 7.004 \\
\hline 138 & 338.0 & & 5.650 & 9.214 & & 4.927 & 5.667 \\
\hline 139 & 283.0 & & & & & & \\
\hline 140 & 366.0 & & & & & & \\
\hline 141 & 240.8 & & & & & & \\
\hline 142 & 273.5 & & & & & & \\
\hline 143 & 232.3 & & & & & & \\
\hline 144 & 256.3 & & & & & & \\
\hline 145 & 166.5 & & & & & & \\
\hline 146 & 139.8 & & & & & & \\
\hline 147 & 91.7 & & & & & & \\
\hline 148 & 87.3 & & & & & & \\
\hline 149 & 5.5 & & & & & & \\
\hline 150 & 78.6 & & & & & & \\
\hline 151 & 7.0 & & & & & & \\
\hline 152 & 26.7 & & & & & & \\
\hline 153 & 12.3 & & & & & & \\
\hline 154 & 9.3 & & & & & & \\
\hline 155 & 23.1 & & & & & & \\
\hline 156 & 36.8 & & & & & & \\
\hline 157 & 23.5 & & & & & & \\
\hline 158 & 37.5 & & & & & & \\
\hline 159 & 4.5 & & & & & & \\
\hline 160 & 33.5 & & & & & & \\
\hline 161 & 2.8 & & & & & & \\
\hline 162 & 2.7 & & & & & & \\
\hline 163 & 1.3 & & & & & & \\
\hline 164 & 1.8 & & & & & & \\
\hline 165 & & & & & & & \\
\hline 166 & 1.3 & & & & & & \\
\hline 167 & 1.3 & & & & & & \\
\hline 168 & & & & & & & \\
\hline 169 & 3.2 & & & & & & \\
\hline 170 & & & & & & & \\
\hline 171 & & & & & & & \\
\hline 172 & & & & & & & \\
\hline 173 & & & & & & & \\
\hline 174 & & & & & & & \\
\hline 175 & & & & & & & \\
\hline 176 & & & & & & & \\
\hline 177 & & & & & & & \\
\hline 178 & 1.1 & & & & & & \\
\hline
\end{tabular}


WSRC-STI-2008-00130

Revision 0

\begin{tabular}{|c|c|c|c|c|c|c|c|}
\hline \multirow[t]{2}{*}{ Mass\# } & \multirow{2}{*}{$\begin{array}{l}\text { Sludge } \\
\text { SRAT } \\
\text { Receipt }\end{array}$} & \multicolumn{3}{|c|}{ Supernate, mg/kg } & \multicolumn{3}{|c|}{ Supernate Slurry Basis. mg/kg } \\
\hline & & $\begin{array}{c}\text { SRAT } \\
\text { Receipt }\end{array}$ & $\begin{array}{c}\text { SRAT } \\
\text { Product }\end{array}$ & $\begin{array}{c}\text { SME } \\
\text { Product }\end{array}$ & $\begin{array}{c}\text { SRAT } \\
\text { Receipt }\end{array}$ & $\begin{array}{c}\text { SRAT } \\
\text { Product }\end{array}$ & $\begin{array}{c}\text { SME } \\
\text { Product }\end{array}$ \\
\hline 179 & & & & & & & \\
\hline 180 & 1.7 & & & & & & \\
\hline 181 & 3.2 & & & & & & \\
\hline 182 & 1.9 & 1.654 & & & 1.385 & & \\
\hline 183 & & 0.880 & & & 0.738 & & \\
\hline 184 & 1.9 & 1.938 & & & 1.624 & & \\
\hline 185 & & & & & & & \\
\hline 186 & & 1.829 & 0.457 & & 1.533 & 0.399 & \\
\hline 187 & & & & & & & \\
\hline 191 & & & & & & & \\
\hline 193 & 3.1 & & & & & & \\
\hline 194 & & 0.197 & & & 0.165 & & \\
\hline 195 & & 0.166 & & & 0.139 & & \\
\hline 196 & 7.3 & 3.482 & & & 2.917 & & \\
\hline 197 & 17.8 & 0.162 & 0.990 & & 0.136 & 0.863 & \\
\hline 198 & 1035.0 & 441.638 & 8.025 & 1.452 & 370.004 & 6.997 & 0.893 \\
\hline 203 & 3.1 & 0.032 & & & 0.027 & & \\
\hline 204 & 1320.0 & 596.845 & 11.353 & & 500.037 & 9.900 & \\
\hline 205 & 6.7 & 0.032 & & & 0.027 & & \\
\hline 206 & 72.4 & 0.054 & 2.607 & & 0.045 & 2.273 & \\
\hline 207 & 72.4 & & 3.519 & & & 3.069 & \\
\hline 208 & 167.8 & 0.097 & 7.014 & & 0.082 & 6.116 & \\
\hline 230 & & & & & & & \\
\hline 232 & 420.0 & & & & & & \\
\hline 233 & 1.2 & & & & & & \\
\hline 234 & 6.0 & & & & & & \\
\hline 235 & 272.5 & & 3.259 & 0.322 & & 2.842 & 0.198 \\
\hline 236 & 12.0 & & & & & & \\
\hline 237 & 33.7 & & 0.184 & & & 0.160 & \\
\hline 238 & 47425.0 & 5.631 & 572.325 & 62.383 & 4.718 & 499.068 & 38.366 \\
\hline 239 & 170.0 & & & & & & \\
\hline 240 & 19.8 & & & & & & \\
\hline 241 & 6.6 & & & & & & \\
\hline 242 & & & & & & & \\
\hline 243 & 5.9 & & & & & & \\
\hline
\end{tabular}




\section{Distribution:}

J.E. Marra, 773-A

J.C. Griffin, 773-A

C.W. Gardner, 773-A

D.A. Crowley, 999-W

A.B. Barnes, 999-W

B.J. Giddings, 786-1A

L.M. Chandler, 773-A

F.M. Pennebaker, 773-A

M.J. Barnes, 773-A

N.E. Bibler, 773-A

C.C. Herman, 773-42A

M.E. Smith, 999-W

M.E. Stone, 999-W

C.J. Bannochie, 773-42A

R.E. Eibling, 999-W

D.C. Koopman, 999-W

D.P. Lambert, 999-W

J.M. Pareizs, 773-A

D.K. Peeler, 999-W

B.R. Pickenheim, 999-W

S.H. Reboul, 773-42A

S.D. Fink, 773-A

D.T. Hobbs, 773-A

K. P. Crapse, 773-43A

D. J. McCabe, 773-42A

C.J. Martino, 773-42A

J.E. Occhipinti, 704-S

R.T. McNew, 704-27S

J.F. Iaukea, 704-30S

J.W. Ray, 704-S

B.A. Davis, 704-27S

T. L. Fellinger, 704-28S

A.V. Staub, 704-27S

H.B. Shah, 766-H

J.M. Gillam, 766-H

H.H. Elder, 704-30S 